\title{
ENVIRONMENTAL AWARENESS LEVEL OF RURAL WOMEN TO MAINTENANCE SOME AGRICULTURAL NATURAL RESOURCES IN MINYA AND FAYOUM GOVERNORATES
}

\author{
MERVAT SEDKE ABD EL WAHAB EI SAID \\ Agricultural Extension and Rural Development Research Institute, ARC, Giza, Egypt \\ (Manuscript received 6 September 2016)
}

\begin{abstract}
$\mathrm{T}$ he study aimed at determining the level of environmental awareness of rural woman, and identifying knowledge level of plant genetic resources as a source to save agricultural natural resources, As well as the relationship between social and economic independent variables and total degrees of environmental awareness maintenance of agricultural natural resources, in addition perception of their problems, identifying the strengths, weaknesses, opportunities and challenges for maintenance agricultural natural resources.The research was conducted in Minya and Fayoum, Governorates based on percentage of pollution for Nile water, air and soil, and these governorates located in the first rank based on these criteria. Accordingly two districts were selected with two villages from each district, namely (sandfa, shalgam) villages from bane mazar district, Minya governorate, and (kalmsha, el sada) from Etsa district Fayoum governorate. Data were collected from sample of 194 rural women, using personal interview questionnaire, frequencies, percentages and simple correlation coefficient were used for data analyzing.
\end{abstract}

The most important results of the analysis as follows;

1. The results showed that (40\%) of respondents were found in the middle Level category of the total degree of environmental awareness compared to $35 \%$ of respondents located in the low category.

2. There was a positive correlation between the following social - economic independent variables: current age, year's number of experience in agriculture, agricultural holding, number of agricultural operations involved and the total degree of environmental awareness maintenance of agricultural land, while there were negative correlation between agricultural holding, number of agricultural operations involved, and the total degree of environmental awareness maintenance of water irrigation, while it appositive between age, average education of family members and the total degree of environmental awareness maintenance air.

3. The results showed that $(61 \%)$ of respondents were found in the middle Level category of the knowledge about plant genetic resources.

4. The most important social and economic problems caused by depletion of agricultural natural resources low of productivity by $(97 \%)$, suffering from poverty by ( $94 \%)$, and migration of young people by( $80 \%)$. 
مستوى الوعى البيئى للمر أة الريفية بصيانة بعض الموارد الطبيعية الزراعية بمحافظتى المنيا و الفيوم

$$
\text { مرفت صدقى عبد الوهاب السيد }
$$

قسم بحوث المرأة الريفية معطز بحوث الارشاد الزراعى والنتصية الريفية بمركز البحوث الزراعية -

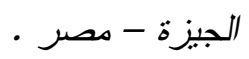

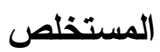

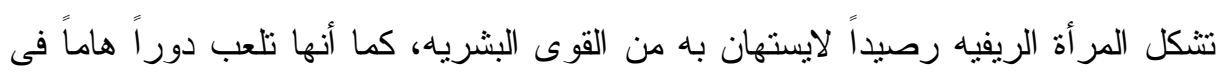

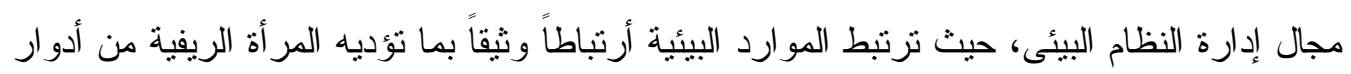

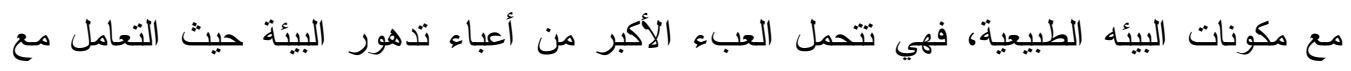
المو ارد الطبيعية من حيث الإستهلاك و التعامل.

ولهذا يستهدف البحث التعرف على مستوى الوعى البيئى للمر أة الريفية بقرى الدراسة، والتعرف على مستوى معرفة المر أة الريفية بصيانة الموارد الور اثية النباتية كمصدر لحفظ الموارد الطبيعية الزراعية، وتحديد طبيعة العلاقة بين المتغيرات المستقلة الدروسة ودرجة الوعى البيئى بصيانة

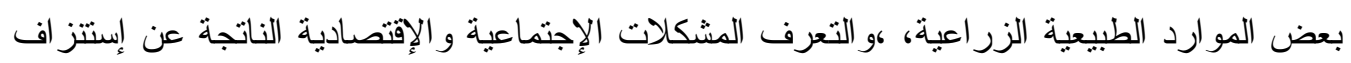

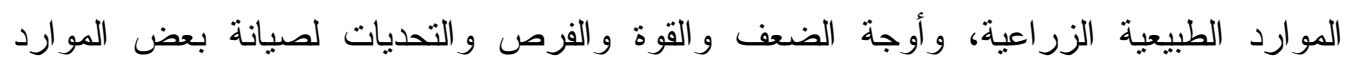
الطبيعية الزر اعية بقرى الدراسة. وقد إجرى البحث في كل من محافظتى المنيا والفيوم وفقاً لبعض المعايير ذات العلاقة بمؤشر نلوث مياه نهر النيل، وتلوث الهواء، وتلوث الأرض لهذا تم إختيار مركزيين من المحافظات المختارة،

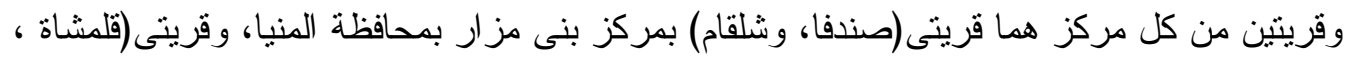
السعدة) بمركز اطسا بمحافظة الفيوم.

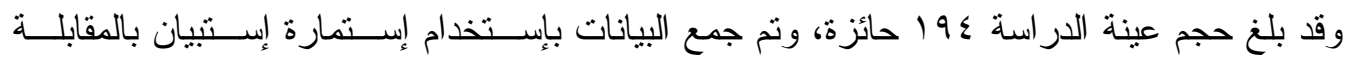
الثخصية، وتم إستخدام التكرار ات و النسب المئوية، وإختبار معامل الإرتباط البسيط.

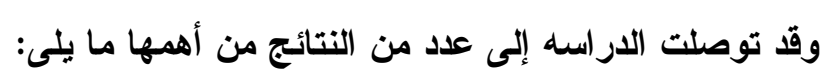

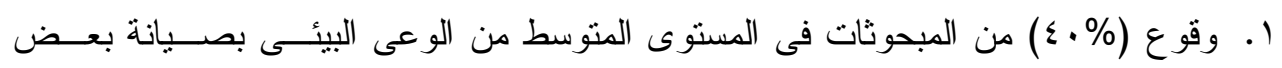

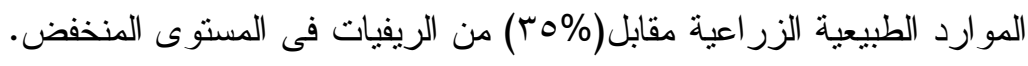

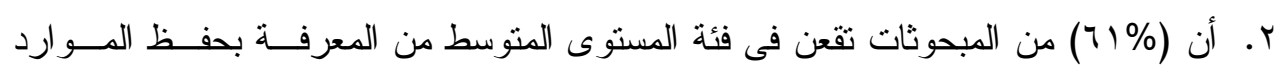


r. وجود علاقة معنوية طردية بين عمر المبحوثة ،عدد سنوات الخبرة فى الزر اعة ، الحيــازة

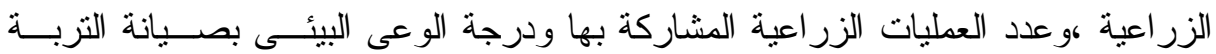

الزر اعية، فى حين كانت العلاقة عكسية بين الحيازة الزر اعية، و عدد العمليــات الزر اعيــة المشاركة بها ودرجة الوعى البيئى البيئى بصيانة مياه الرى، بينما العلاقة طردية بين عمر

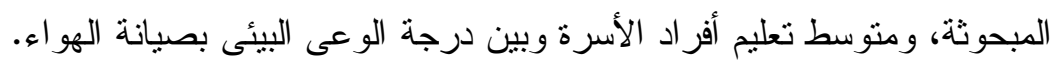

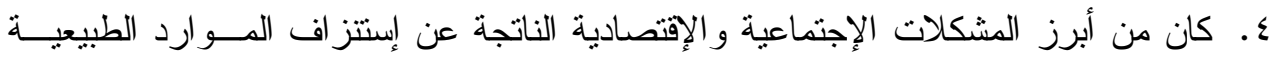

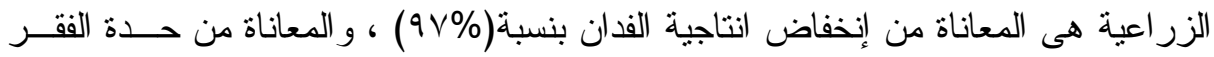

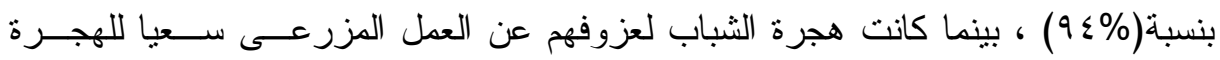

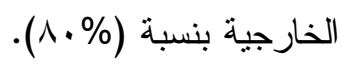

تُعد البيئة أساساً للتتمية الإجتماعية والإقتصادية وتعد التتمية المستدامة ذلك النهج الذى يوفق بين حماية وصيانة الموارد البيئية بما فيها الموارد المتجددة وغير المتجددة من جهة وبين منطلبات التتمية القائمة على تلبية الإحتياجات وعدم الإسنتز اف من جهة أخرى مما يحد من التهديديات البيئية ويجنب المجتمع أثنار ها. وفى جميع أنحاء العالم تتعرض سلسلة نظم الإتتاج الزر اعي للخطر نتيجة مزيج من الضغوط السكانية

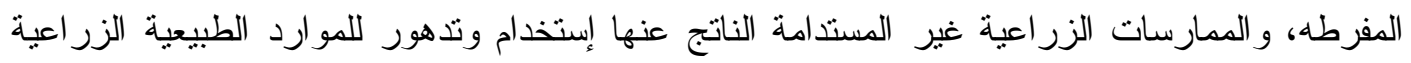

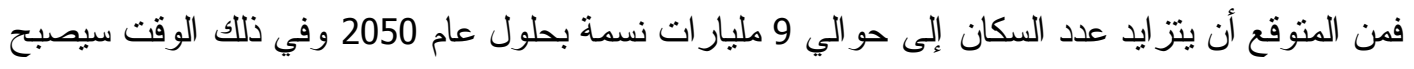

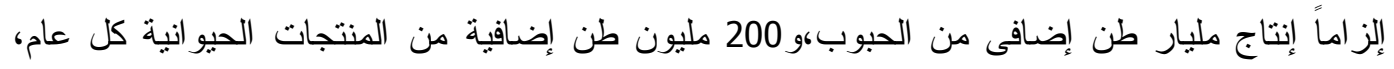

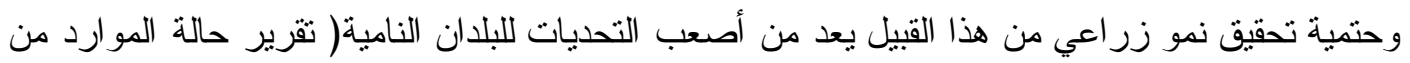

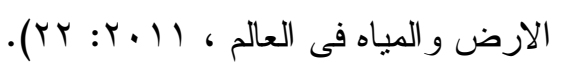

وتعد مناطق الدول العربية من أكثر مناطق العالم ندرة فى موارد الأر اضى الزر اعية و المياه إضافة إلى ضعف الكفاءة الإقتصادية في إستخدامها، الأمر الذى يحد من المز ايا النسبية فى إنتاج العديد

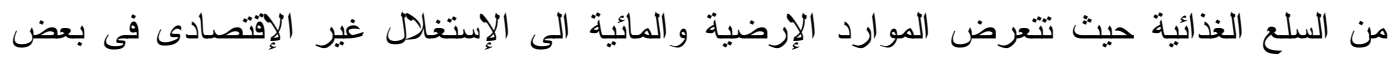

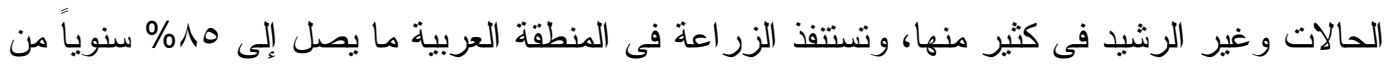

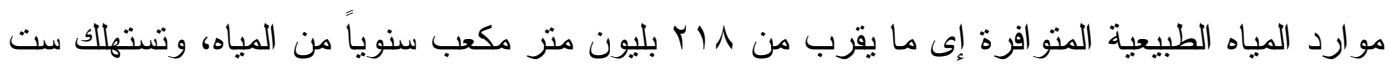

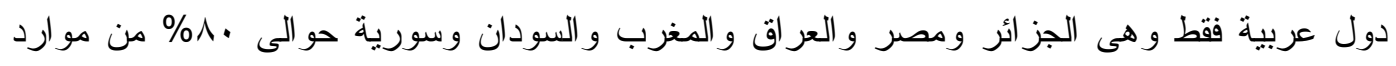

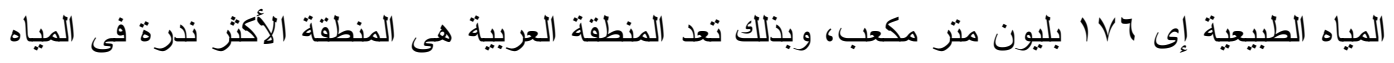

$$
\text { على مستوى العالم. }
$$

فى حين يصيب التصحر وتدهور الأر اضى سبعة عثر دولة عربية ويجعل الأراضى الصالحة للزرعة

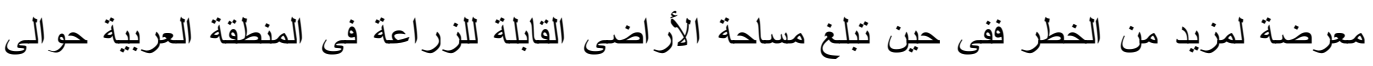

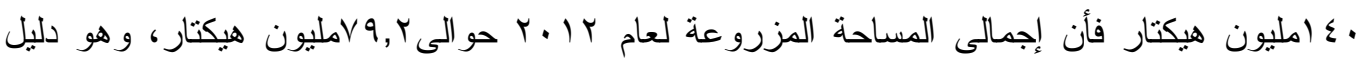


على ضعف الكفاءة الإقتصادية بإستغلال الموارد المتاحة (الإستر اتيجية العربية للحد من مخاطر

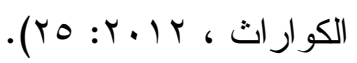

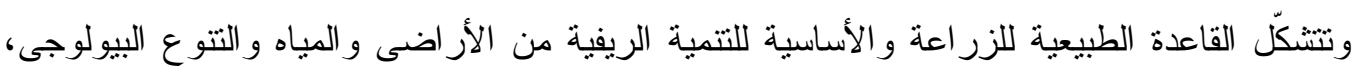

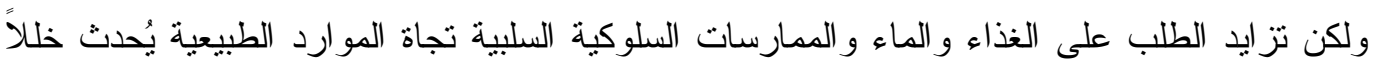

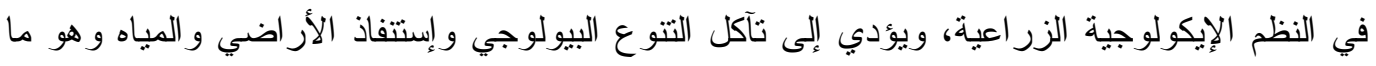

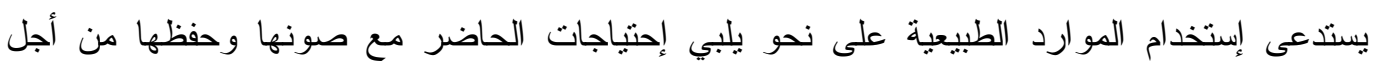

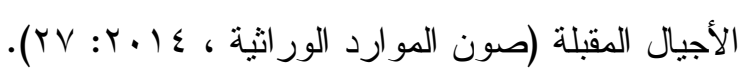

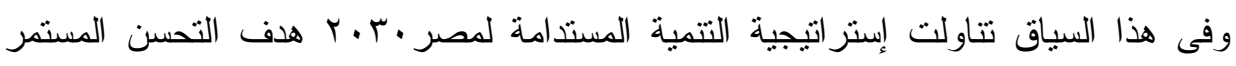

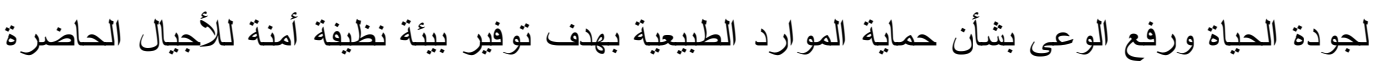

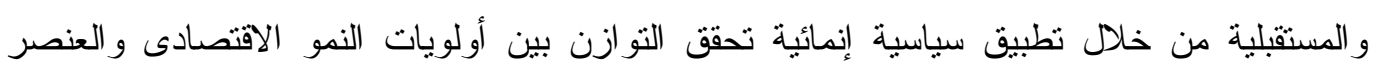

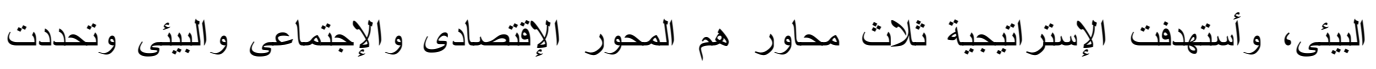

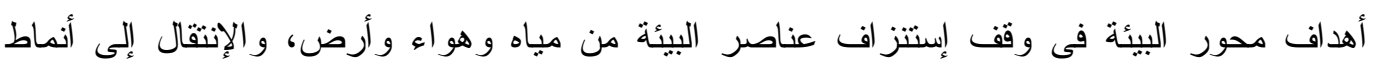

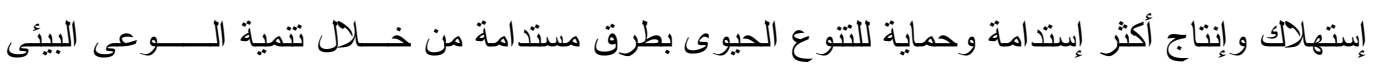

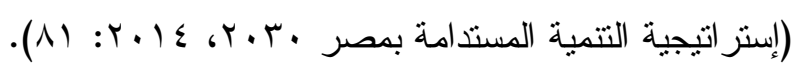

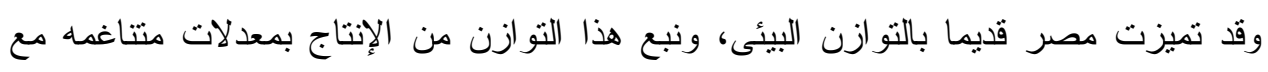

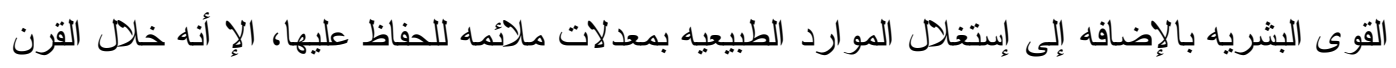
الماضى حدث تغيير فى أساليب إستغلال موارد الأرض وتفاقمت الأثار الضاره بالبيئه نتيجة الأنشطة الإنها البشرية غير الملائمة للطبيعه البيئية و أصبحت مصر تعانى من العديد من مشكلات النلوث البيئى وتتفاقم

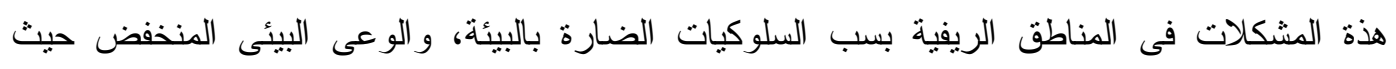

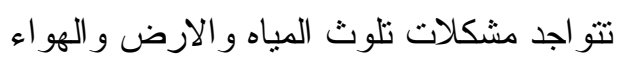
وعن تلوث الهو اء لوحظ أن مشكلة إدارة المخلفات الصلبه لاتز ال قائمة فى كل المحافظات

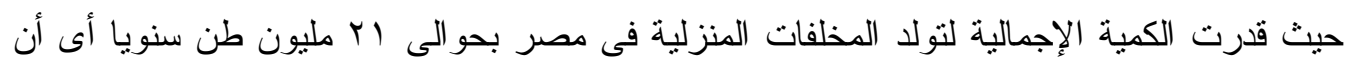

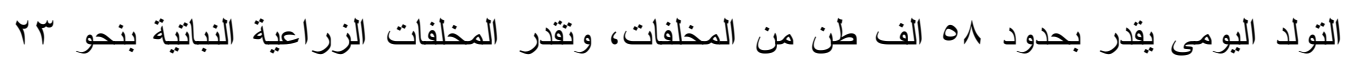

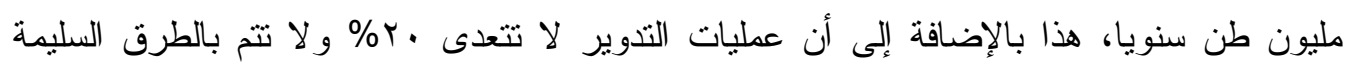

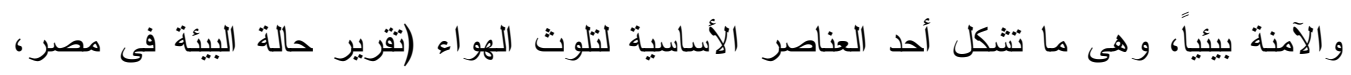
(rov: r. 10 وتعد مشكلة الحفاظ على المو ارد الطبيعة الزر اعية ما هى الإمشكلة سلوك إنسانى لهذا فأن

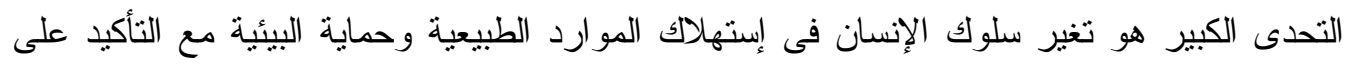

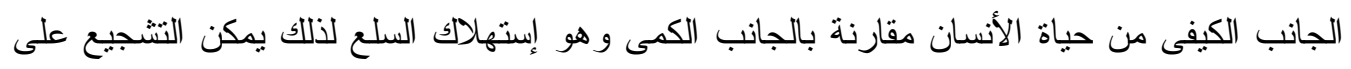

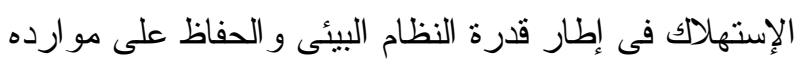

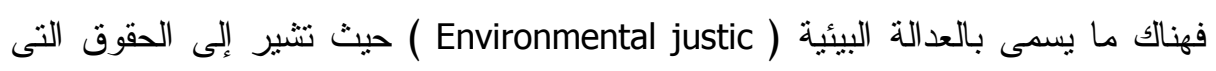

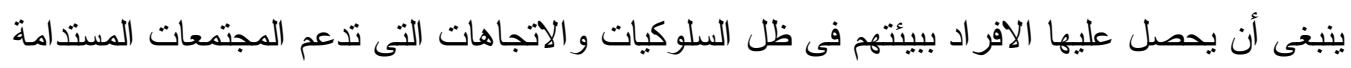


حيث يستطيع الفرد التعامل مع الموارد البيئية بطرق مستدامة بيئيًا للحفاظ على حق الاجيال القادمــة

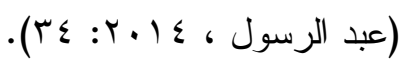

وتعد صيانة الموارد الطبيعية والإستخدام المستدام لها من خلال الممارسات الزراعية الامنة عنصرين لمقومات الإستدامة في قطاع الزر اعة بما يسهم فى التخفيف من وطأة الفقر ، ففهوم

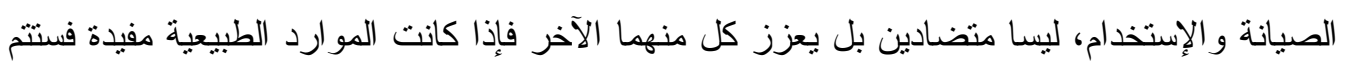

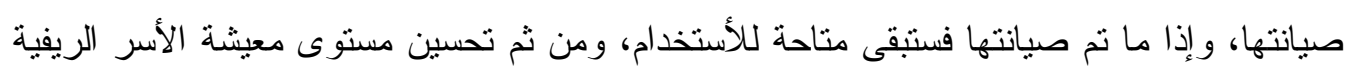
عبر المهارات و المعارف و الوعى البيئى بكيفية الحفظ والإستخدام، و الوعي هو فهم للحقائق المتعلقه بمشكلة أو ظاهره ما، وبالتالى فهم الظاهرة، وبما أن الظاهرة هنا تتعلق بحفظ وصيانة وإستخدام

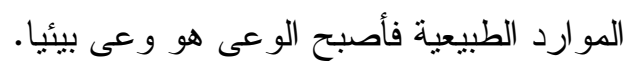

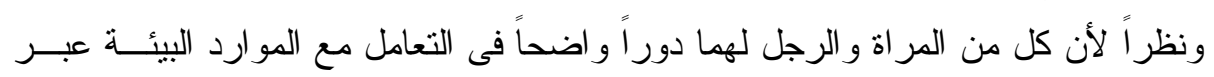

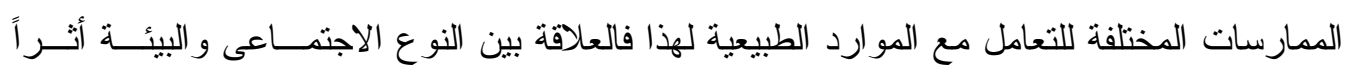

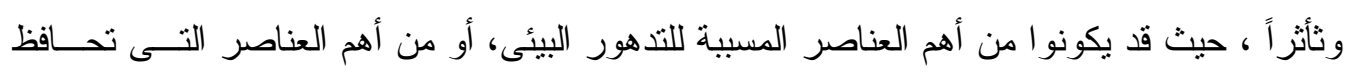

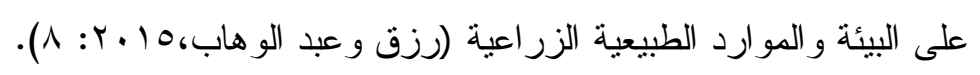

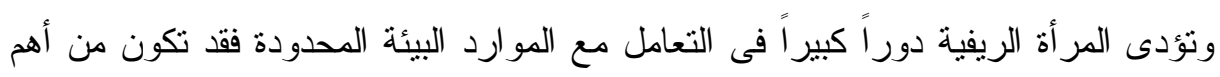

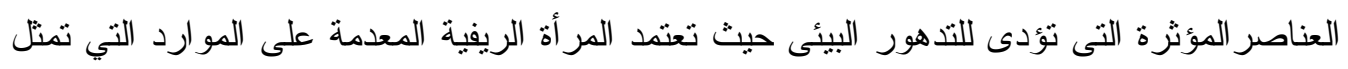

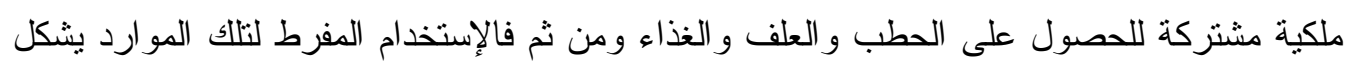
تهديداً خطير اً لسبل العيش في الريف و إستنز افا للمو ارد الطبيعية، أو قد تكون المر أة من أهم العناصر

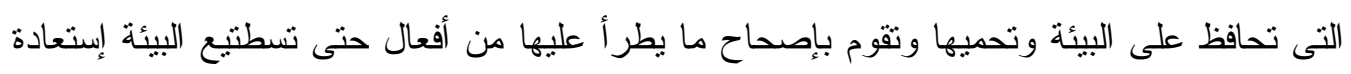

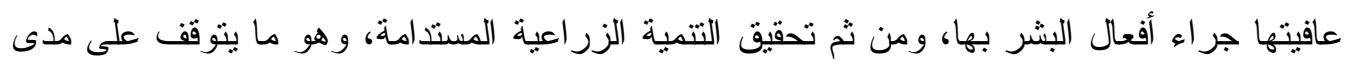

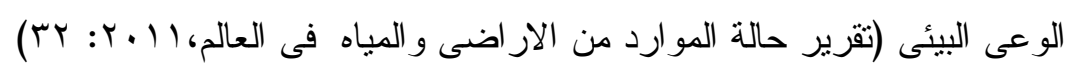

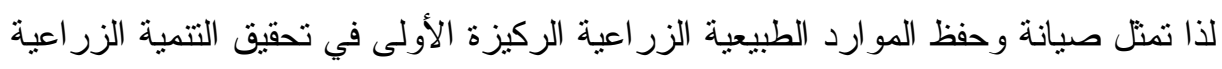

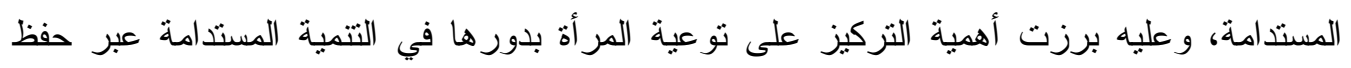

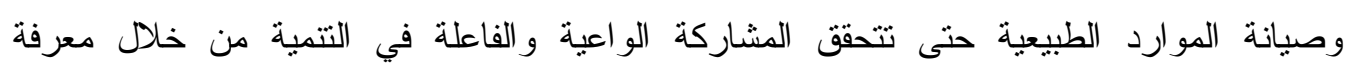

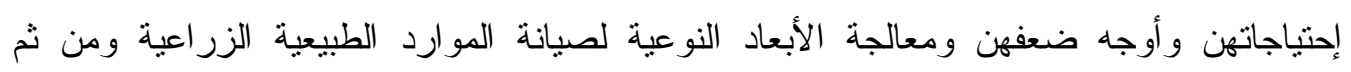
إستخدامهن للمو ارد بشكل مستدام يخدم الأجيال الحالية و المستقبلية.

\section{المشكلة البحثية : البنية}

تعتبر الزراعة ركيزة أساسية للتنمية ببعديها الإقتصادي و الإجتماعي، وفي العقود الثلاثة

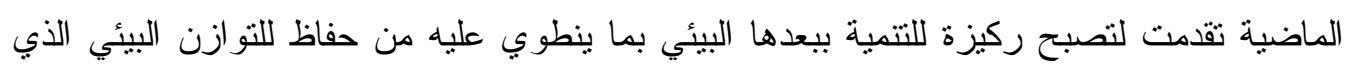

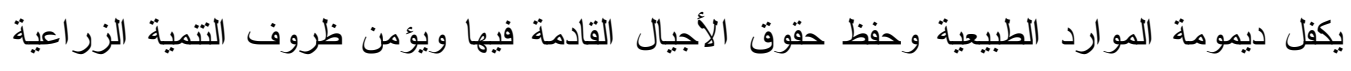
المستدامة.

وفى ضوء الأدوار القائمة والمتوقعة من الريفيات حيث التعامل المباشر مع الموارد

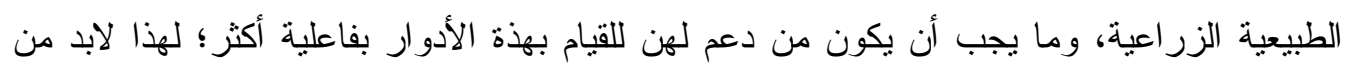

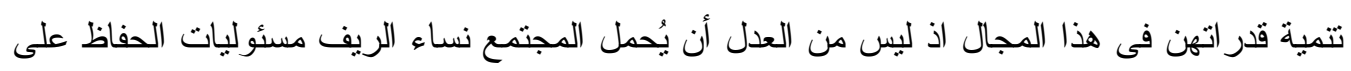


البيئة و الإستخدام المستدام للموارد الطبيعية الزراعية دون تهيئتهن لذلك، ومن ثم فأن تحليل وفهم ومعرفة مسئوليات المر أة الريفية فيما يتعلق بحفظ وصيانة المو ارد الطبيعية الزر اعية لتحقيق التتمية

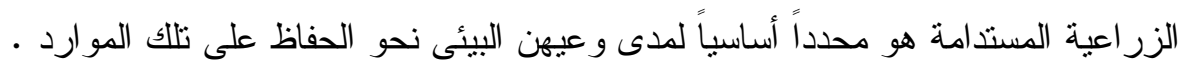
لهذا تبلورت مشكلة البحث فى محاولة الإجابة على التساؤلات الاتية:

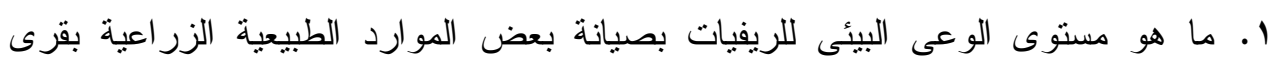

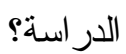
r. تحديد مستوى معرفة المرأة الريفية بصيانة الموارد الور اثية النباتية كمصدر لحفظ بعض

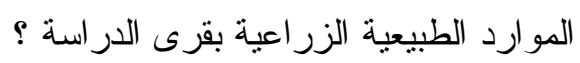
r. تحديد طبيعة العلاقة بين المتغيرات الإجتماعية والإقتصادية المستقلة المدروسة ودرجة الوعى البيئى للريفيات بصيانة بعض المو ارد الطبيعية الزر اعية بقرى الدراسة ؟

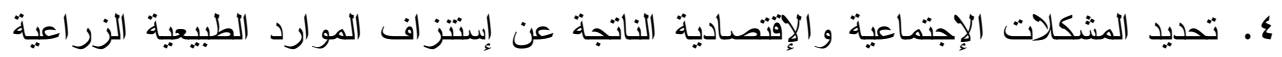
من و جهة نظر المبحوثات بقرى الدراسة؟

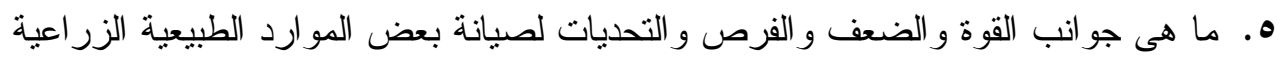
من وجهة نظر المبحوثات بقرى الدر اسة ؟ مو و

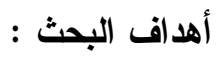

ا. التعرف على مستوى الوعى البيئى للمر أة الريفية بصيانة بعض الموارد الطبيعية الزراعية

$$
\text { بقرى الدر اسة. }
$$

r. التعرف على مستوى معرفة المرأة الريفية بصيانة الموارد الور اثنة النباتية كمصدر لحفظ

$$
\text { بعض المو ارد الطبيعية الزر اعية بقرى الدر اسة. }
$$

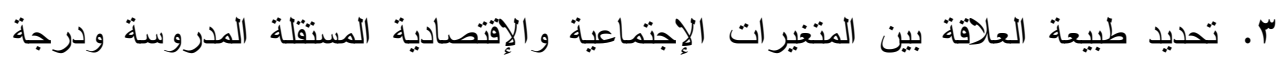
الوعى البيئى للريفيات بصيانة بعض المو ارد الطبيعية الزر اعية بقرى الدراسة.

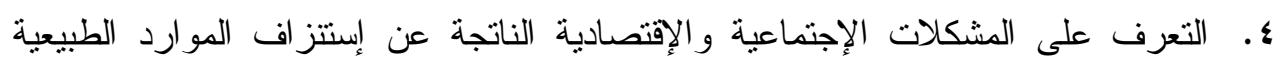

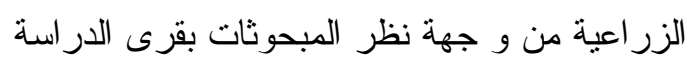
هـ التعرف على جوانب القوة و الضعف والفرص و التحديات لصيانة بعض المو ارد الطبيعية الزر اعية من وجهة نظر المبحوثات بقرى الدراسة. أهمية البحث:

نظر اً لأهمية دور المر أة الريفية فى التعامل مع الموارد الطبيعية الزراعية فقد تضمنت

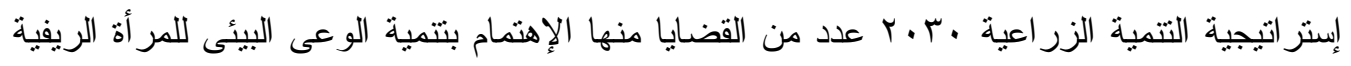

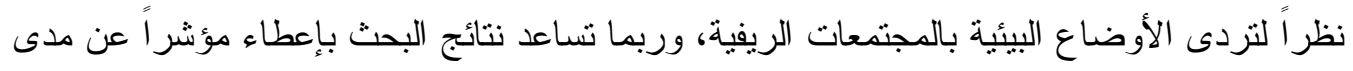

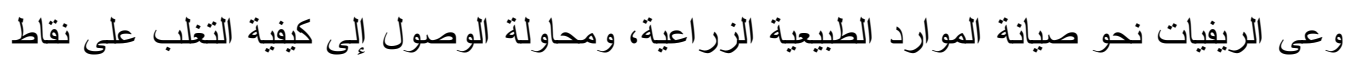

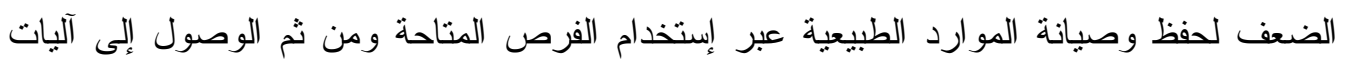
تناعد على حفظ الموارد الطبيعية الزراعية يمكن وضعها أمام متخذى القرار فضلاً عن إعطاء 
معبراً بكيفة إسخدام معارف الريفيات بتوظيف الموارد الورانية النباتية لصيانة الموارد الطبيعية الزر اعية.

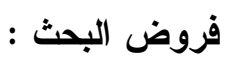
لتحقيق هدف البحث الثالث تم وضع الفروض البحثية التالية :

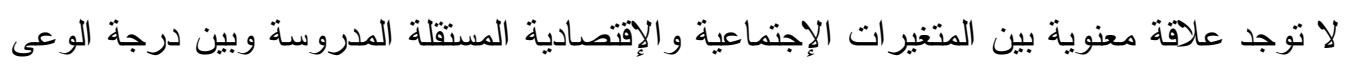
البيئى للريفيات بصيانة بعض الموارد الطبيعية الزر اعية وأنبثق منة الفروض البحثية التالية:

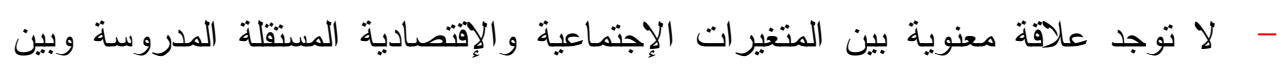

درجة الوعى البيئى للريفيات بصيانة التربة الزراعية كأحد الموارد الطبيعية الزر اعية.

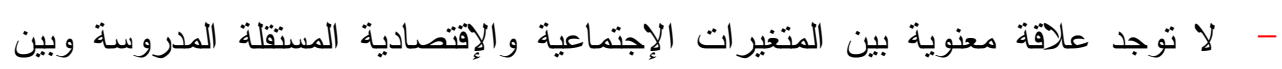

درجة الوعى البيئى للريفيات بصيانة مياه الرى كأحد الموارد الطبيعية الزر اعية.

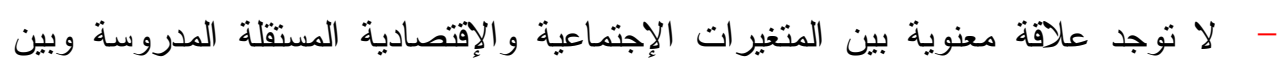
درجة الوعى البيئى للريفيات بصيانة الهواء كأحد المو ارد الطبيعية الزر اعية.

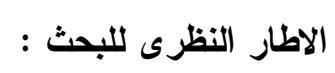

تعتمد الأدوار التى تؤديها المرأة الريفية فى الزراعة بشقيها النباتى و الحيوانى ومختلف

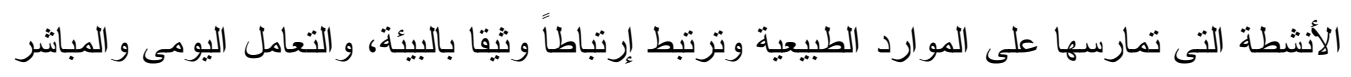

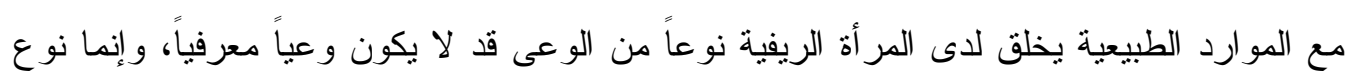
من الإدر الك الأولى للعلاقة بين الذات و الموارد الطبيعية. و اذا تشكل الوعى البيئى المو الىى للسلوكيات الايجابية أدى الى تحقيق العدالة البيئية وهى الحقوق التى

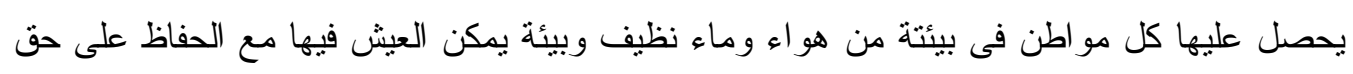

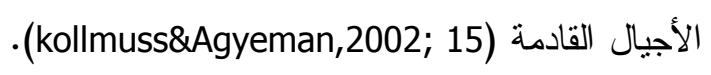
وتتكل النساء أغلبية قوة العمل الزراعية، وهو ما يوضح تعامل المرأة مع الموارد

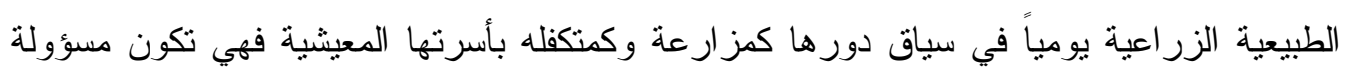

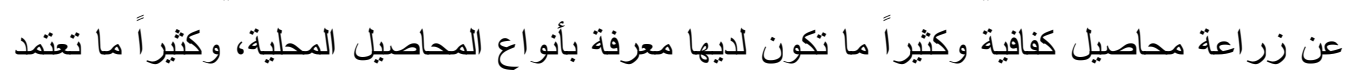

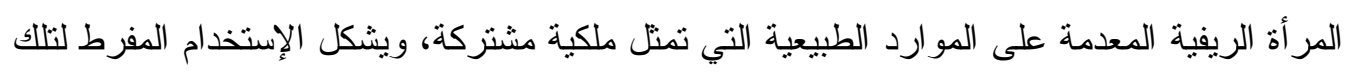

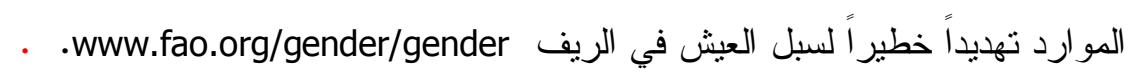

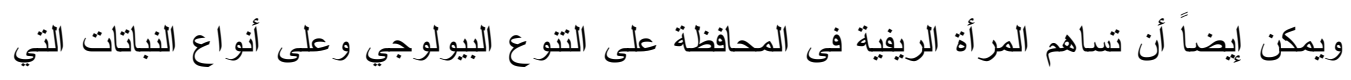
تستوطن المنطقة التى تعيشها، وذلك من خلال التعرف على هذه الأنو اع، و على كيفية المحافظة عليها ومحاولة إكثار ها. فالموارد الور اثنية النباتية هى مصدر لكائن حى نباتى قد يكون كامل أو جزء منة ولة قيمة إقتصادية ويستخدم فى الزر اعة و إنتاج الغذاء وتتقسم إلى موارد ور اثثية نباتية خاصة باصنية بالمحاصيل

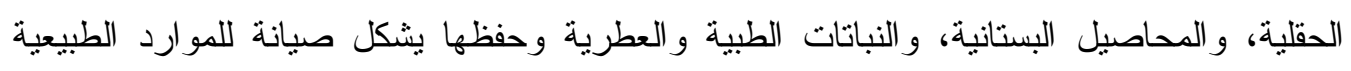

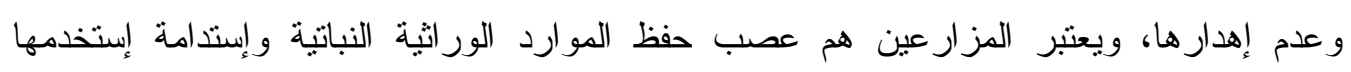




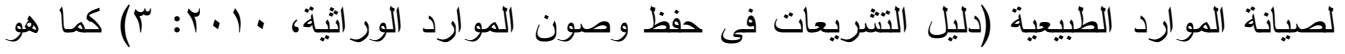
موضح بالثكل التالى.

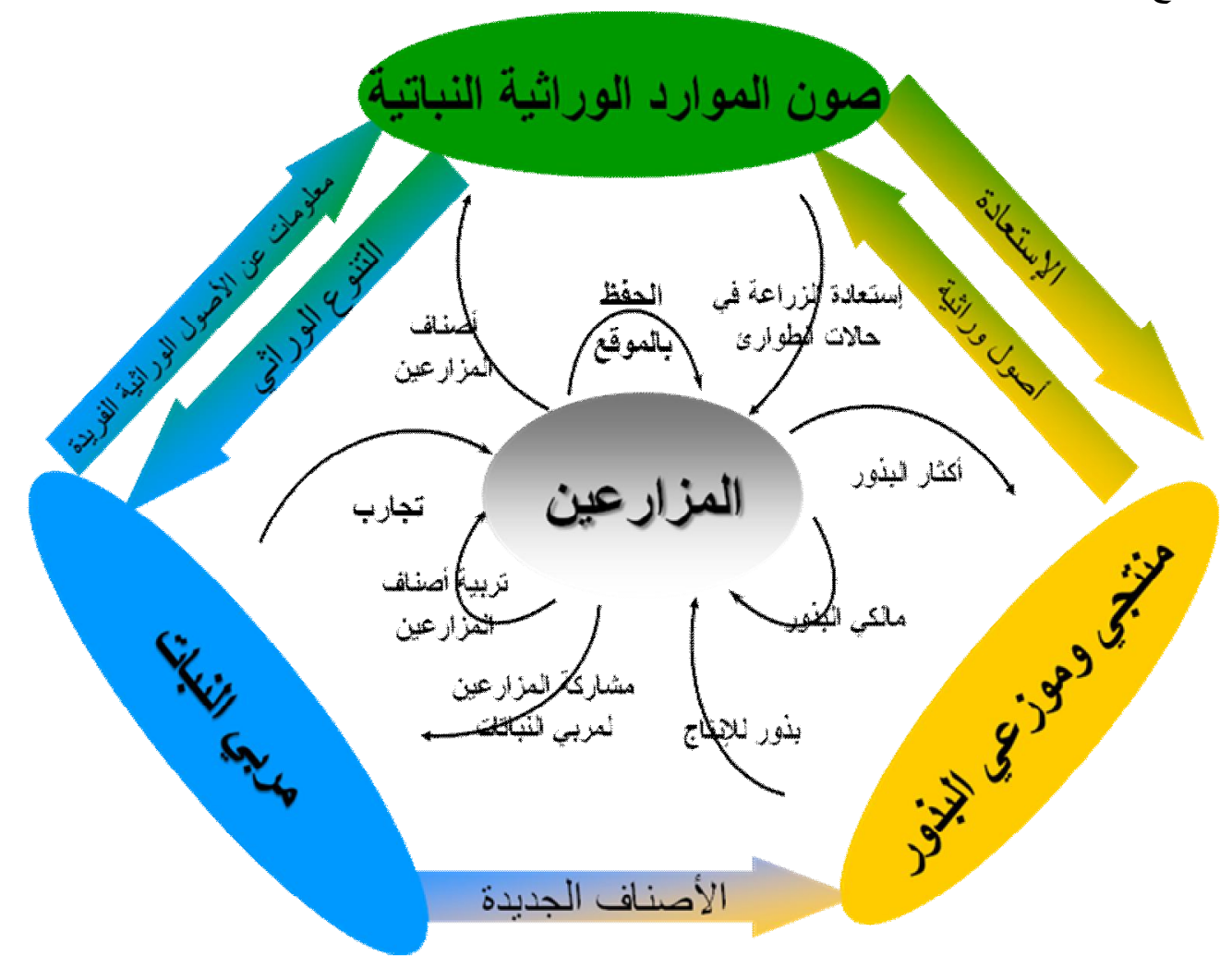

The role of biotechnology in exploring and protecting agricultural genetic

resources, FAO, ROME, 2006 (Editors: John Ruane and Andrea Sonnino)

و المورد الور اثي ليس هو فقط ذلك الأصل الوراثي النباتي أو الحيواني أو الكائن الدقيق

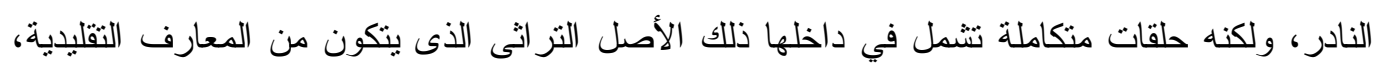

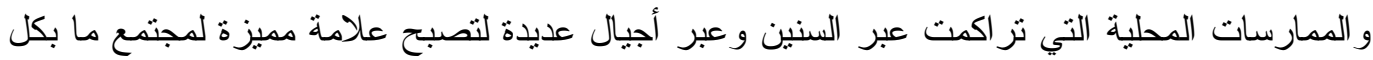
ما فيه من معارف وخبرات، حيث قد تؤدى الريفيات دوراً عبر معرفتهن بحفظ وصيانة الموارد الدئ الور اثية النباتية وتوظيفها من أجل صيانة الموارد الطبيعية الزر اعية كما موضح بالثكل التالى . 


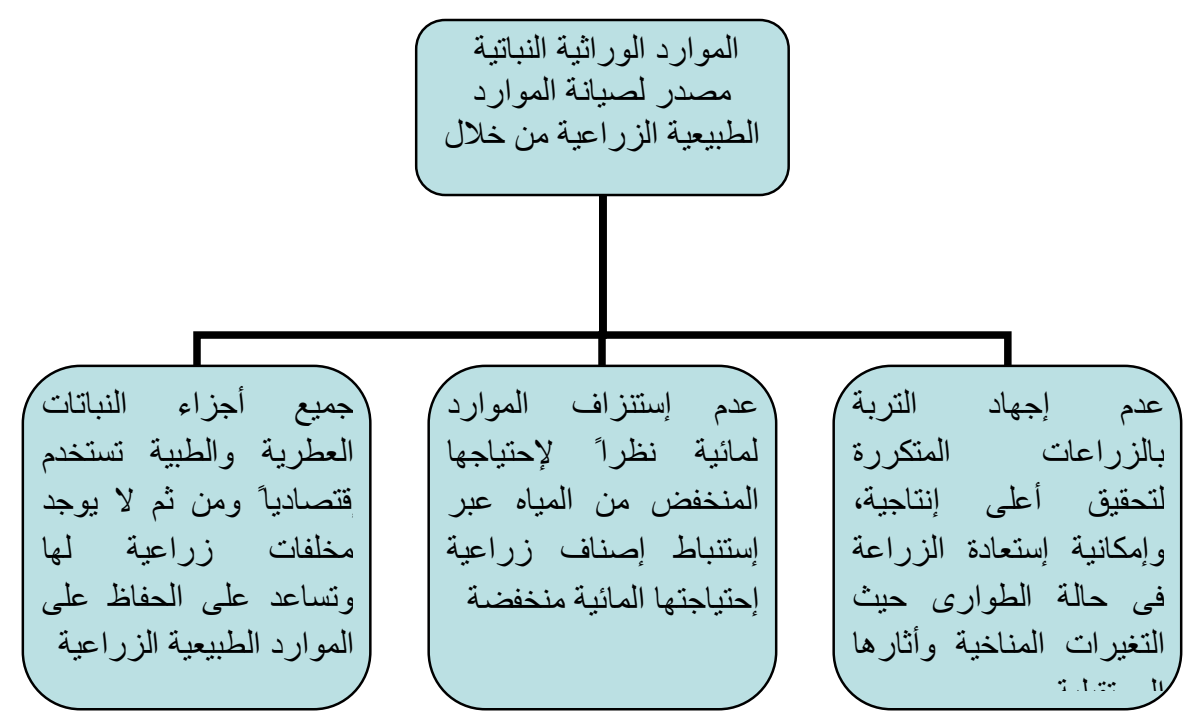

ومن ثم تظهر العلاقة ذات التأثير والتأثر بين المرأة الريفية والموارد الطبيعية الزراعية، وهناك العديد من الدراسات التى تناولت دراسة دور الزراع ( رجالا ونساء) فى الحفاظ على البيئة وكان من أبرز نتائج تلك الار اسات مايلى :

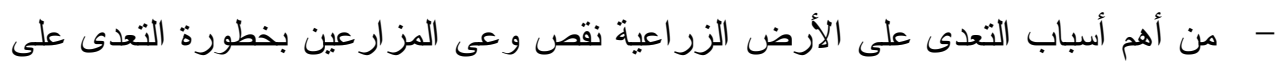

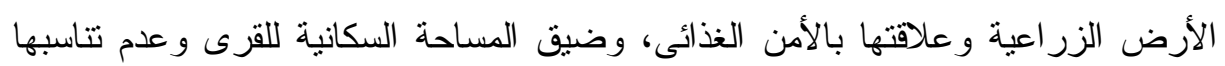

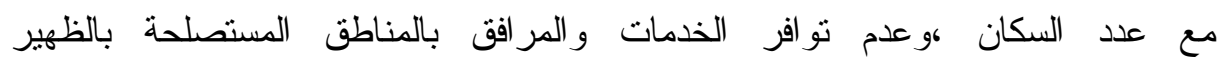

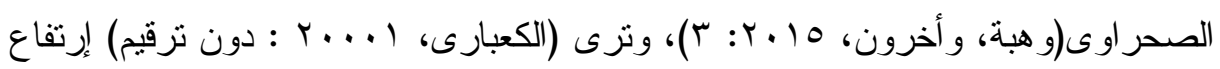
مستوى معرفة وتتفيذ المبحوثين الذكورعن الإناث بممارسات الحفاظ على الأرض و المياه

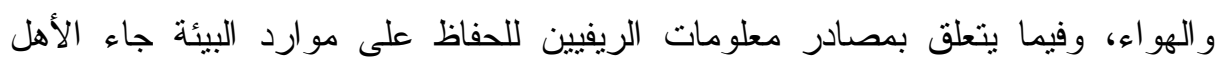

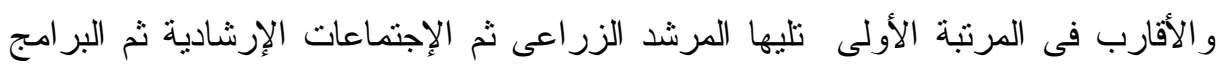

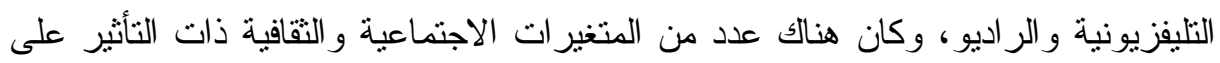

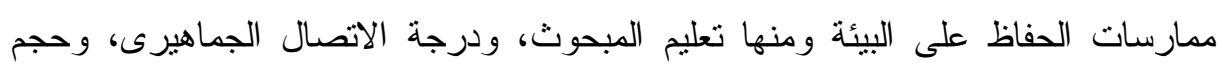

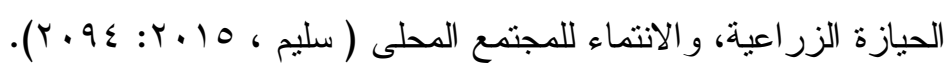

ونجد أن معظم الدراسات السابقة قد تتاولت معرفة وممارسات الريفيين نحو الحفاظ على مو ارد البيئة، ولكن دون النظر الى مدى معرفة خبرة النساء الريفيات فى حفظ وصيانة الموارد الوراثية النباتية

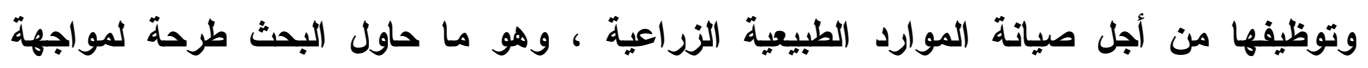
إستنز اف الموارد الطبيعية الزر اعية.

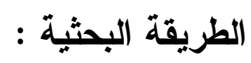

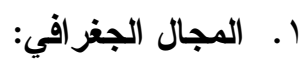
تم إختبار منطقة البحث وفقاً لثلاث معايير وهى نسبة تلوث الأرض الزر اعية ، نسبة نلوث الهواء ،

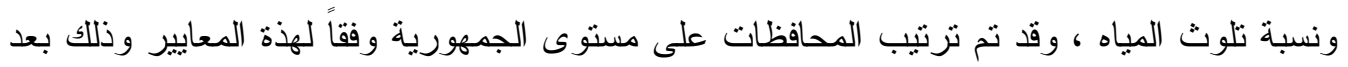

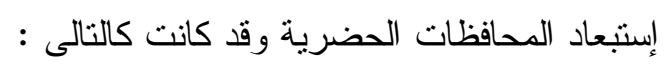


من مصادر تلوث التربة الزراعيه الهواء الجوى: يعتبر تلوث الهواء من أخطر أنواع النلوث البيئى و أكثر ها شيو عا حيث يترسب الهو اء الملوث على سطح التربة نتيجة للجاذبية كنواتج حرق الوقود من دخان ثانى أكسيد الكربون و تكوين مركبات سامة مثل المركبات النتروجينية و المركبات الأكسجينية و الهالوجينات المشعة، ومن ثم فأن المنطقة التى تثتعرض

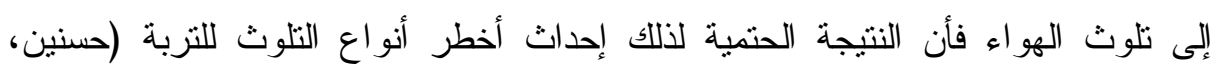

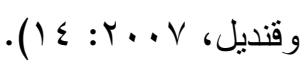
ووفقاً لهذا فقد إحتلت محافظة الفيوم المركز الأول من حيث نسبة التلوث للهو اء بالجسيمات

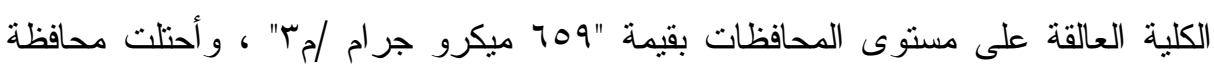

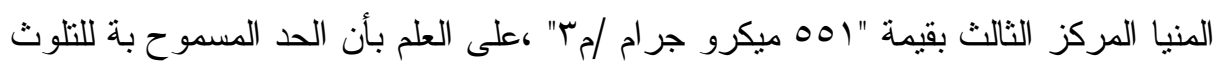
بالجسيمات الكلية العالقة هو .9 ميكرو جرام /مَّ وفقاً لتوصيات المرصد البيئى (الجهاز

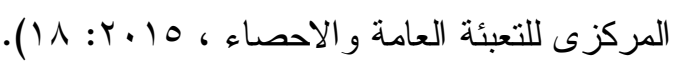

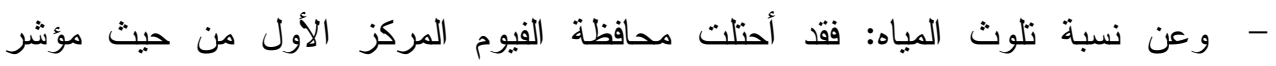

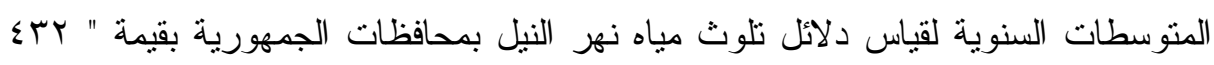

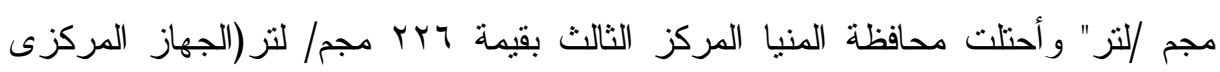

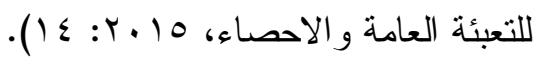

وتعذر الوصول إلى البيانات السابقة على مستوى المر اكز و القرى لهذا تم إختبار هم بطريقة عشو ائية

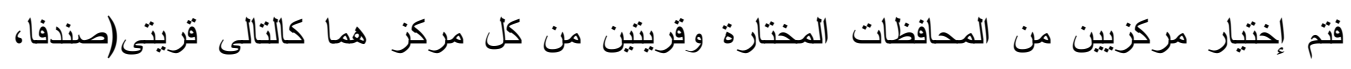
وشلقام) بمركز بنى مز ار بمحافظة المنيا، وقريتى(قلمشاة ، السعدة) بمركز إطسا بمحافظة الفيوم.

r. المجال البشري وطريقة اختيار العينة:

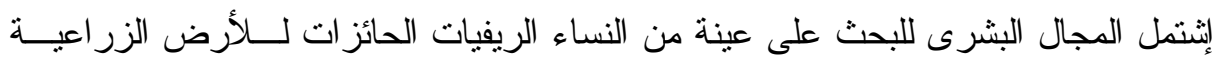

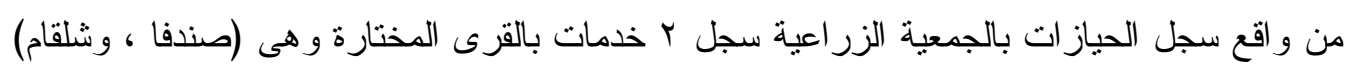

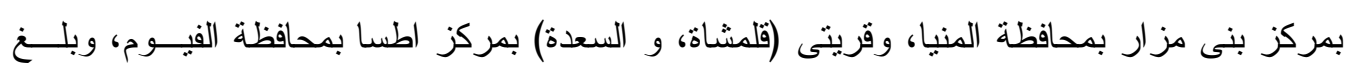

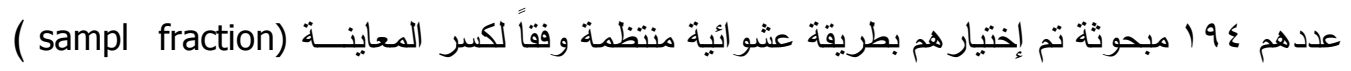

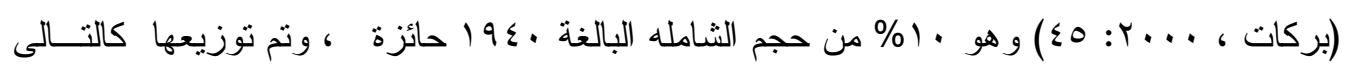

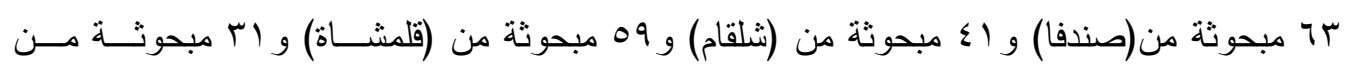

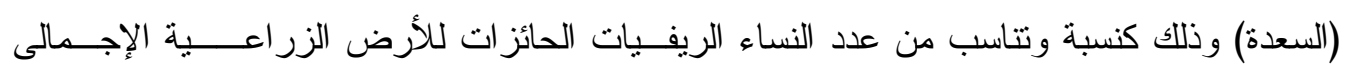

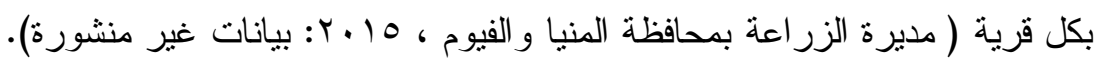

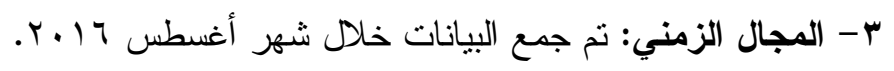

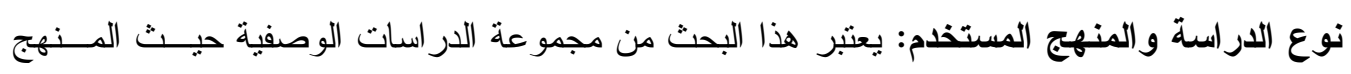

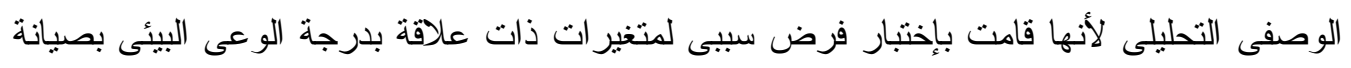
بعض الموارد الطبيعة الزر اعية حسب فروض الدراسة النظرية.

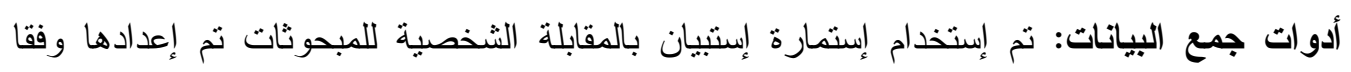
لأهداف البحث وتم إختبار ها مبدئيا على خمسة عشر مبحوثة، وتم إجر اء التعديلات اللازمة. 
الأدوات الإحصائية المستخدمة في البحث: تم إستخدام العرض الجدولى بالأعداد و التكرارات و النسب المئوية لعرض النتائج ، وإختبار معامل الارنباط البسيط لبيرسون وتحليل(SOWT).

متغيرات البحث وتعريفاته الإجرائية وكيفية قياسه: اولاً : الوعى البيئى للريفيات بصياتة الموارد الطبيعية الزر اعية:

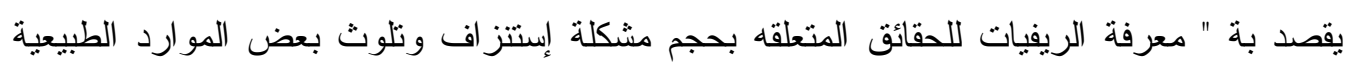
الزر اعية وكيفية صيانتها لكل من مورد الأرض الزر اعية، ومياه الرى، و الهو اء".

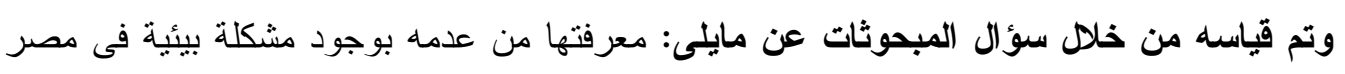

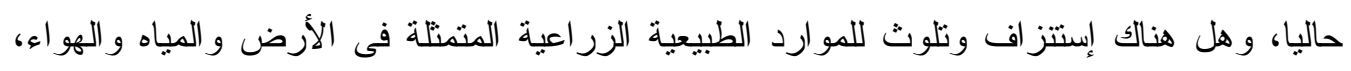

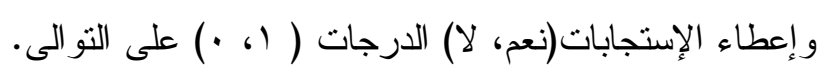

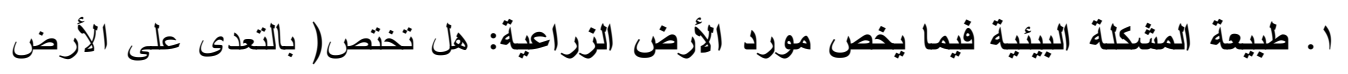

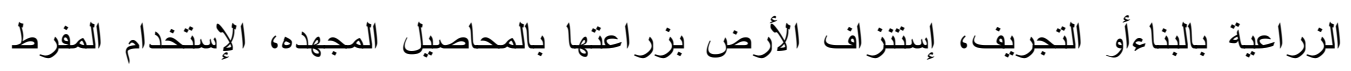

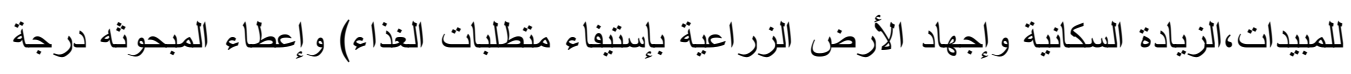

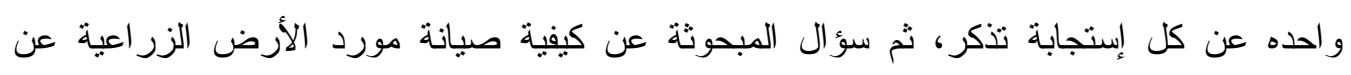

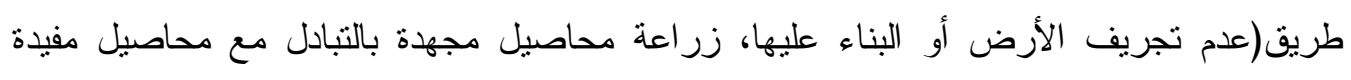
للتربة كالبقوليات، إستخدام مخلفات المحاصيل كاسمدة عضوية، عدم الاستخدام المفرط للمبيدات) و إعطاء المبحوثه درجة واحده عن كل إستجابة تذكر .

r. طبيعة المشكلة البيئية فيما يخص مورد مياه الرى: هل تختص( بنقص مياه الرى من المنبع

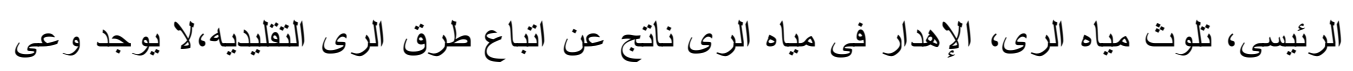

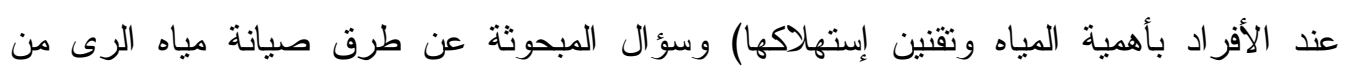

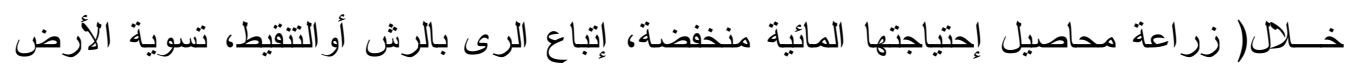

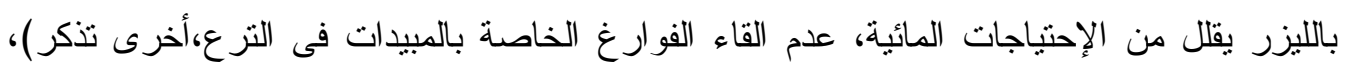
و إعطاء المبحوثة درجة عند كل إستجابة تذكر . بالئن

r. طبيعة المشكلة البيئية فيما يخص مورد الهواء: هل تختص (بالإستخدام المفرط للمبيدات

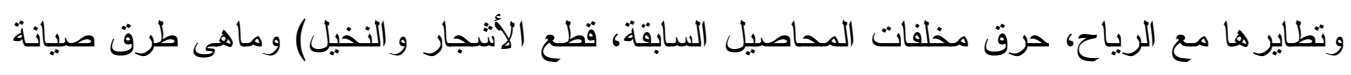

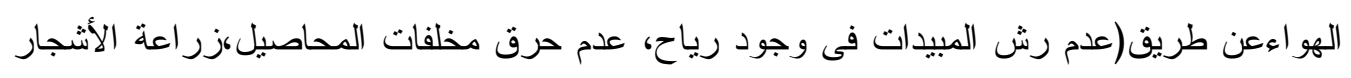

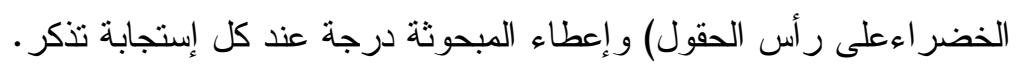
وتم جمع الدرجات الخاصة بإستجابة المبحوثات لتعبر عن درجة الوعي البيئى للمر أة الريفية وقد البداء تراوح المدى ما بين (ا، و وب درجة)، وبناء على هذا المدى نم تقسيم وعى المبحوثات الى ثلاث

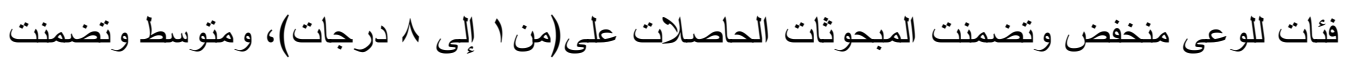

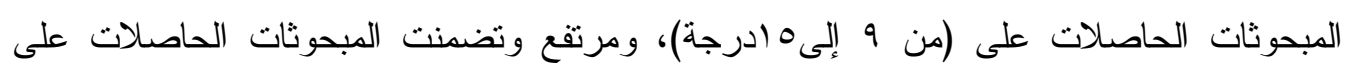


ثانياً: : معرفة المرأة الريفية بحفظ الموارد الوراثية النباتية:

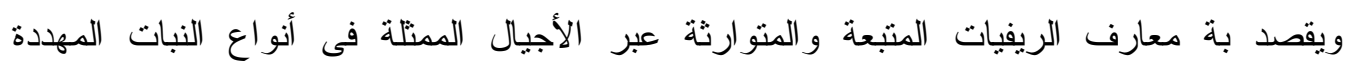

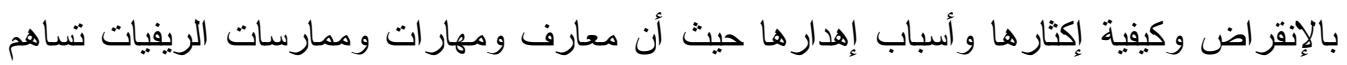
في حفظ وتتمية الموارد الوراثية النباتية التى تعد مخزن للموارد الطبيعية وتساعد على حفظها وصيانتها ومن ثم عدم الإستنز اف للمو ارد الطبيعية.

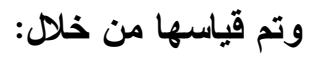

- أهمية الموارد الور اثية النباتية ( كغذاء للانسان، وتنتخدم فى ثتبيث الكثبان الرملية، والحفاظ على الثى

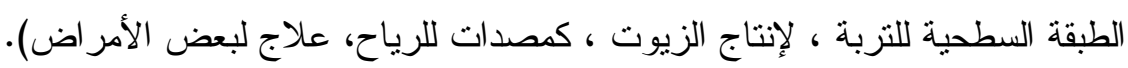

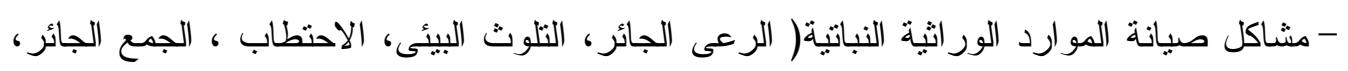
إستير اد أصناف من الخارج مهجنة).

- معرفة المبحوثة بالنباتات المهددة بالإنقر اض من المحاصيل الحقلية (الترمس، الحلبة، فول الصويا،

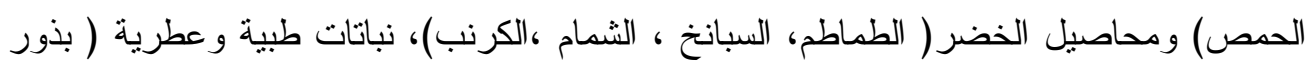

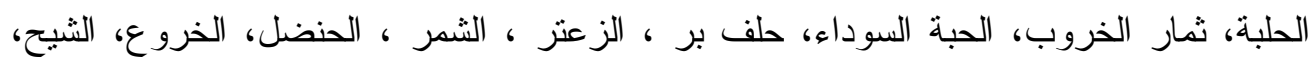
الريحان، البردقوش). - طرق حماية الموارد الور اثثية النباتية( الحد من التلوث، الإكثار، التوارث المعرفى بين الأجيال،

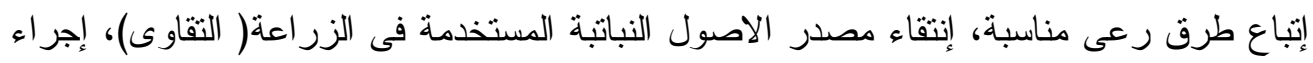

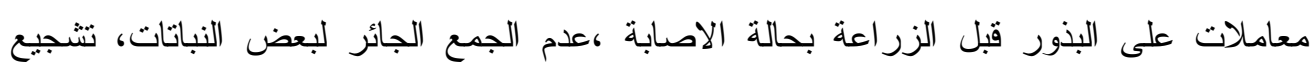
توزيع البذور المحلية ، التخزين الجيد للتقاوى). ونم إعطاء المبحوثة درجة واحدة عن كل بند تعرفة ودرجة صفر في حالة عدم المعرفة وتعبر

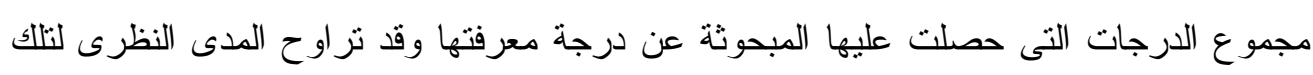

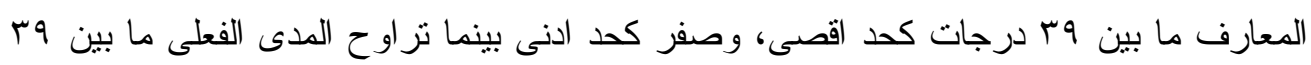
درجة كحد اقصى وه درجات كحد أدنى وبناء على هذا الددى تم تصنيف المبحوثات الى ثلاث

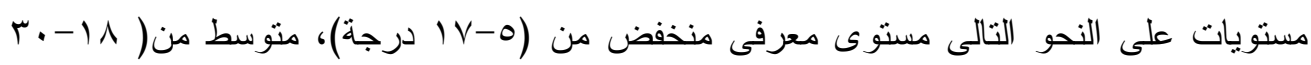
درجة ) ومرتفع من( اس فأكثر درجة).

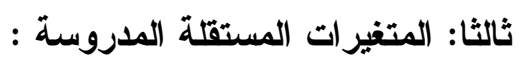
ا.عمر المبحوثة : سن المبحوثة وقت جمع البيانات وعبر عنه بالرقم الخام.

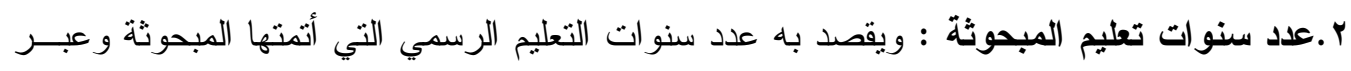

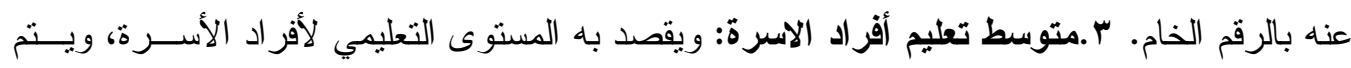
قياسه بجمع عدد سنوات التعليم لكل أفر اد الأسرة وقسمتها على عدد أفراد الأسرة في سن التعاد التعليم.

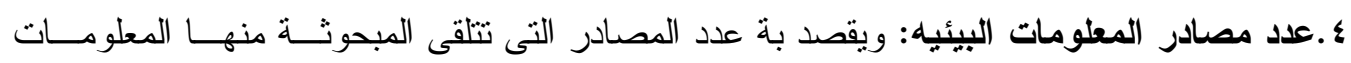

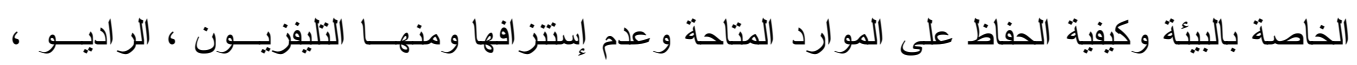

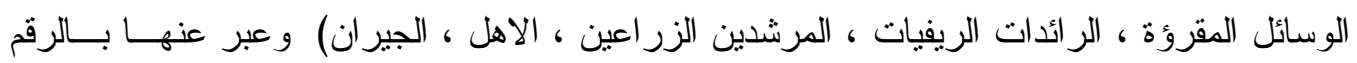


هـ عدد سنوات الخبرة فى الزراعة: وعبر عنها بالرقم الخام لعدد سنوات العمل فى مجال الزر اعـــة فعليًا. 7 الـ درجة المشاركة فى الأنشطه البيئه: ويقصد به درجة مشاركه المبحوثة فـى بعـض الأنشـــه

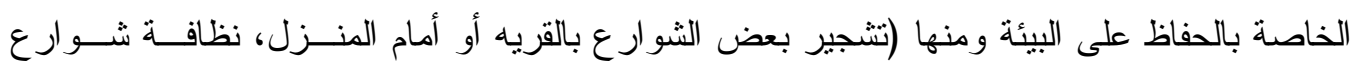

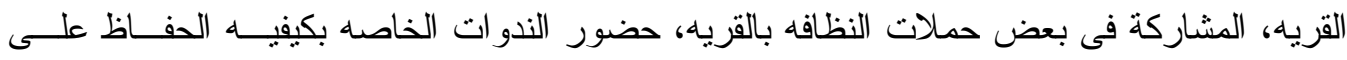

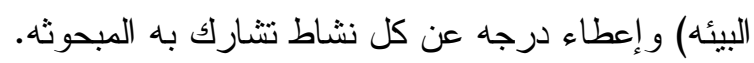
V. الحيازة الزراعية:ويقصد بها إجمالى مساحة الأرض الزراهية داعية التى نقوم المبحوثة بزر اعتها

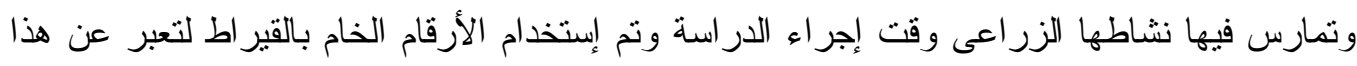
- المتغير ^. عدد العمليات الزراعية المشاركة بها: ويقصد به مدى مشاركة المبحوثة فى العمليات الزر اعيــة

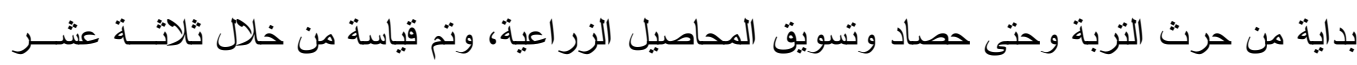

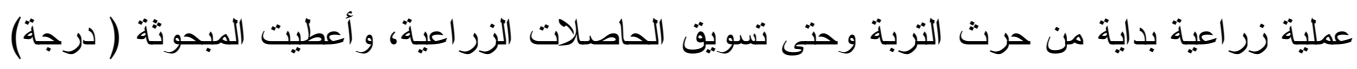

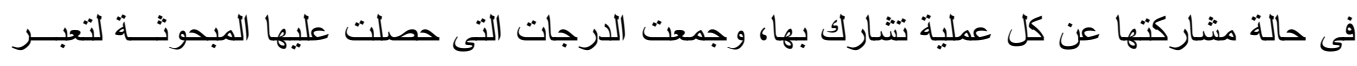

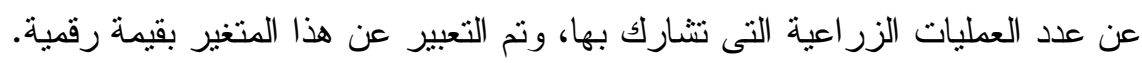
9. الاخل السنوي لأسرة المبحوثه: وتم قياسه من خلاد حساب مجموع الاخول النقدية لجميع أفراد

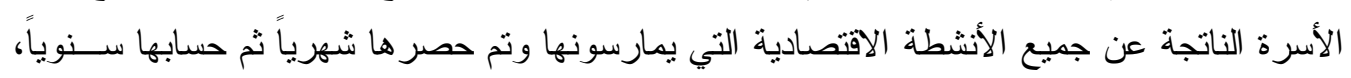

$$
\text { و استخدام الرقم الخام النهائي. }
$$

• 1 ـ نمط إستغلال الأرض الزراعية: ويقصد بة طبيعة الاستفادة و الإستخدام للأرض الزر اعية حيث

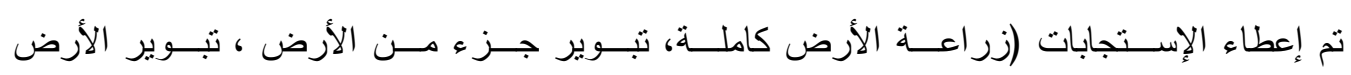

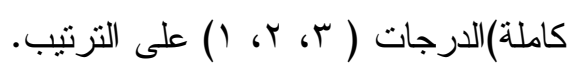

$$
\text { وصف عينة البحث: }
$$

تشير النتائج الواردة بجدول( (1) الى توزيع المبحوثات وفقاً لبعض خصائصهن النى تتاولهـا

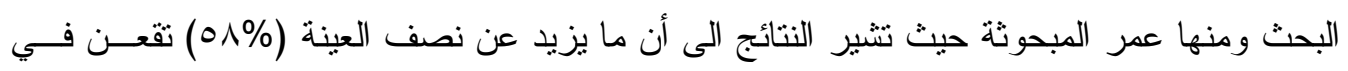

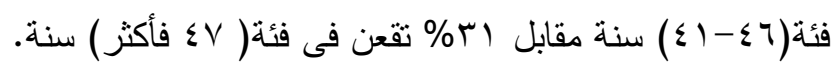

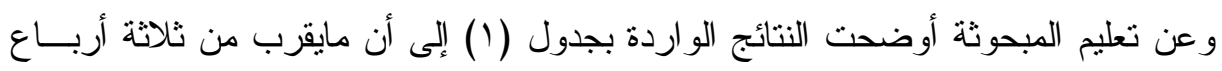

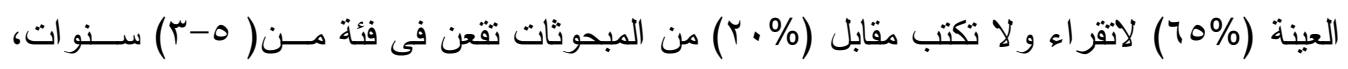

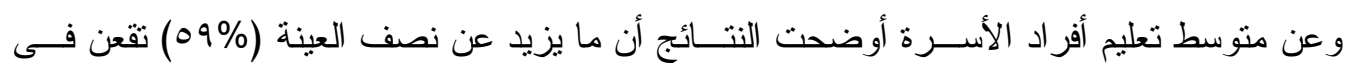
فئة (0- ( ) سنة.

أما عن عدد مصادر المعلومات البيئية تثير النتائج الواردة بجدول (1) إلى ما يقرب من

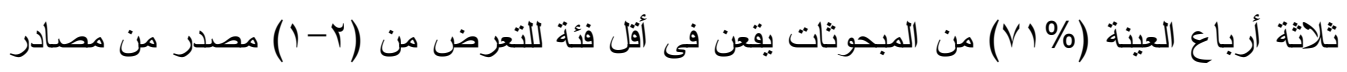

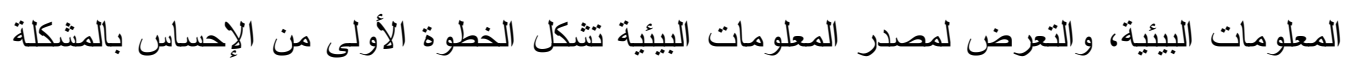

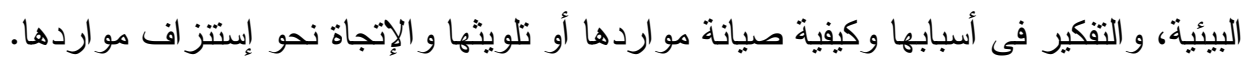


وعن عدد سنوات الخبرة فى الزراعة تشير نتائج الجدول (1) إلى ما يقرب من ثلاثة

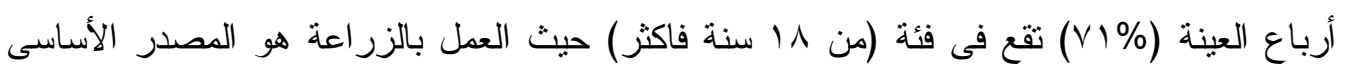
لعمل الريفيات.

أما عن درجة المشاركة فى الأنشطه البيئه تثشير نتائج جدول (1) أن (\%^\%) من

المبحوثات لم يشاركن فى الأنشطة البيئية وهى نتيجة تاليه لإنخفاض تعرض المبحوثات لمصادر المعلومات البيئية حيث أن المشاركة عبارة عن إتخاذ قر ار و القيام بالتتفيذ وفقاً للمعارف التى سبق تكوينها.

وعن الحيازة الزر اعية تشير النتائج الواردة بجدول (1) إلى أن ما يزيد عن نصف العينة

آT\% يقعن فى فئة ( أقل من · ب قير اط) حيث كلما صغرت حجم الحيازة الزر اعية وإزداد دور المر أة الريفية و أنخفض دخلها تتجة إلى الإستخدام المفرط للموارد الطبيعية بإعتبار ها ملكية عامة

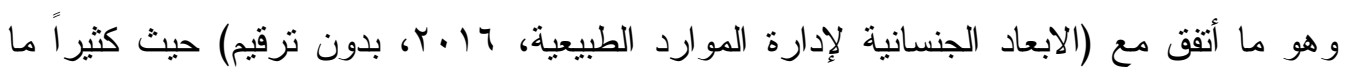
تعتمد المر أة الريفية المعدمة على الموارد الطبيعية ويشكل الإستخدام المفرط لتلك الموارد تهديداً خطير اً لسبل العيش في الريف وللأمن الغذائي.

أما عن العمليات الزر اعية التى تشارك بها المر اة الريفية توضح النتائج الــواردة بالجـدول

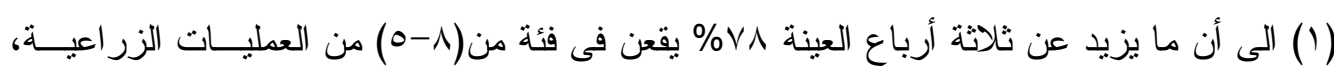
وفيما يتعلق بالدخل أوضحت النتائج ع^\% من المبحوثات تقعن فى فئة الدخل المنخفض.

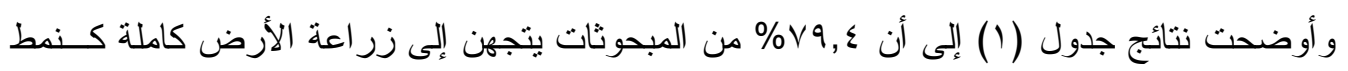
من أنماط إستغلال الأرض الزر اعية .

جدول (1) توزيع المبحوثات وفقاً لبعض خصائصهن الثخصية

\begin{tabular}{|c|c|c|c|c|c|}
\hline$\%$ & عدد & درجة المشاركة فى & $\%$ & عدد & عمر المبحوثة \\
\hline 71 & Irr & لا تشارك & 11 & r) & (0ץ-._£) سة \\
\hline
\end{tabular}




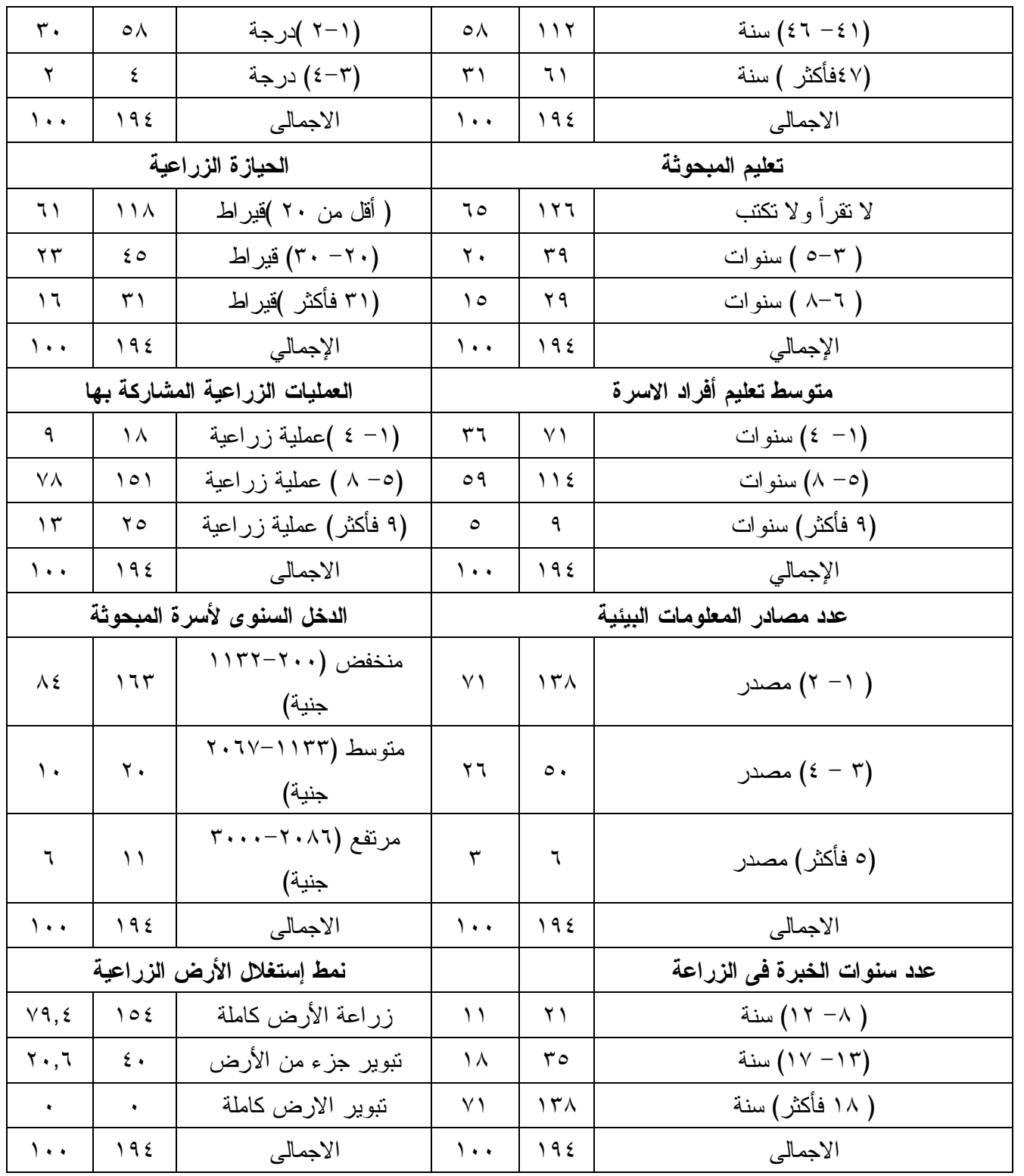

المصدر : جمعت وحسبث من إستمار ات الإستبيان 
تشير النتائج الو اردة بجدول(r) و الخاصة بتوزيع المبحوثات وفقاً لمستوى الوعى البيئى بصيانة الموارد الطبيعية الزراعية إلى أن( \% .ـ؟) من المبحوثات تقعن فى مستوى الوعى البيئى المتوسط، مقابل (\% \%) فى المستوى المنخفض للوعى البيئى، بينما كانت أقل نسبة (\% ( ) من المبحوثات فى المستوى المرتفع، ويمكن تفسير تللك النتيجة فى إطارعدد من المتغيرات الثخصية التى تمنل مؤشراً لعدم الوعى البيئى للريفيات بصيانة الموارد الطبيعية الزراعية والعناصر التى التى تشكل الوعى البيئى لها.

ومن المتغير ات الثخصية إنخفاض المستوى التعليمى للريفيات، وبالتالى عدم قدرتهن على التفكير المستقبلى فى إستنز اف الموارد المتاحة، إيضا التعرض إلى أقل عدد من المصادر المعرفية البيئية وعدم المشاركة فى أنشطة حفظ وصيانة البيئية كما نم إيضاحه فى وصف الخصائص الثخصية للمبحوثات بجدول (1). و هو ما أثقق مع نتائج نقرير (2005, world bank) أنه فى كثير من المناطق الريفية و الصحر اوية بالدول النامية يصعب تقديم الخدمة الزر اعية للنساء إما لصعوبة الوصول إليهم أو لتفنىى الأمية مما يتطلب وسائل غير تقليدية لتوصيل الرسالة فيما يتعلق بحماية البيئة و الحفاظ على مواردها ومدى إستفادتهن و إنعكاس ذلك على رفع مستوى معيشتهم. وعن العناصر التى نتكل الوعى البيئى للمرأة الريفية أوضح نتائج الجدول (Y) أن (\% T\%) من المبحوثات يعرفن أن الأستخدام المفرط للمبيدات هو من أحد مصادر تلوث و إسنتز اف مورد

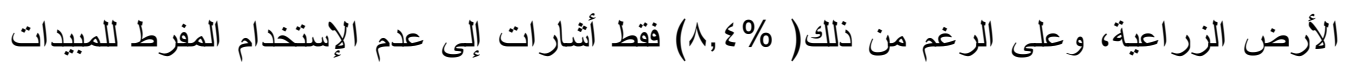
لصيانة مورد الأرض الزر اعية وهو ما يشير إلى هناك فجوة بين الإدر الك والسلوك الموالى للبيئة حيث الفجوة بين المعرفة وكيفية التطبيق. و عن صيانة مياه الرى أوضحت نتائج جدول (Y) أن(\%) من المبحوثات يعرفن أنة لا يوجد وعى من عند الأفراد بأهمية المياه وتقنين إستخدامها و إستهلاكها كأحد الحقائق المتعلقة بصيانة مورد مياه الرى، وجاءات النتيجة المنطقية لعدم الوعى بكيفية الإستهلاك و التقنين أن أقل نسبة من المبحوثات (\%) تعرف بكيفية صيانة مورد مياه الرى من خلال زر اعة محاصيل إحتياجتها المائية منخفضة، و هو ما يمكن تفسيرة بأن المر أة الريفية لا تشارك فى بعض العمليات الزر اعية ومنها الرى وأنها من مهام الرجال، ومن ثم لا يتتكل لديها معرفة بكيفية حفظ وصيانة مورد مياه الرى. 
أما عن صيانة مورد الهو اء أثنار ات نتائج جدول (Y) إلى أن (10\%) من المبحوثات يعرفن بأن حرق مخلفات المحاصيل من أحد أسباب تلوث الهواء، ومن ثم أثنارات (V\%\%) منهن إلى عدم حرق مخلفات المحاصيل كأحد طرق كيفية صيانة مورد الهو اء.

ومن ثم فهذه المتغيرات فى مجملها جعلت (\% (؟) من المبحوثات يقعن فى المستوى المتوسط من الوعى البيئى بصيانة بعض الموارد الطبيعية الزراعية، و(\%\%) تقع فى المستوى المنخفض، و هو ما أتفق مع نتائج دراسة (kollmuss\&Agyeman,2002; 18) و التى أثنار ات إلى أن النساء لديهن معارف بيئية أقل ولكن لديهن نعاطف أكثر نحو الموارد البيئية ولكن هذا لا يجدى نفعاً نحو صيانة الموارد الطبيعية الزر اعية، وأن هناك فجوة بين الإدر الك و السلوك الموالى للبيئة حيث مستوى سلوكهن البيئى متوسطاً وهو ما يوضح الفجوة بين المعرفة و النطبيق.

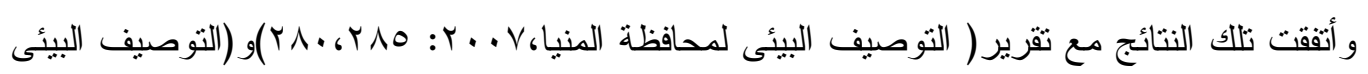

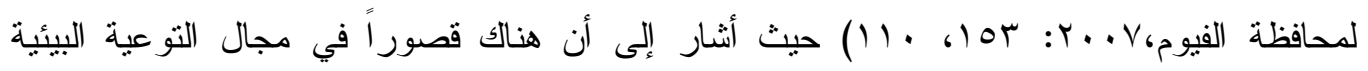
وخاصة في الموضوعات التي تتعلق بالبيئة، و إستخدام المبيدات الزراعية النى تؤدى الى إضرار بالتربة ومياه الرى و الهو اء.

\begin{tabular}{|c|c|c|}
\hline$\%$ & $\begin{array}{c}\text { ع } \\
n=19\end{array}$ & عناصر الوعى البيئى بصيانة بعض الموارد الطبيعية الزر اعية \\
\hline
\end{tabular}




\begin{tabular}{|c|c|c|}
\hline \multicolumn{3}{|c|}{ المعرفة بالحقائق المتعلقة بمورد الأرض الزراعية } \\
\hline $1 \varepsilon$ & tr & التعدى على الأرض الزر اعية بالبناء أو التجريف \\
\hline $7 V$ & $1 \pi$ & الإستخدام المفرط للمبيدات \\
\hline 10 & $r$ r. & إستنز اف الأرض بزر اعتها بالمحاصبل المجهده \\
\hline$\varepsilon$ & 7 & الزيادة السكانية و إجهاد الأرض الزر اعية لإستيفاء منطلبات الغذاء \\
\hline \multicolumn{3}{|c|}{ كيفية صيانة مورد الأرض الزراعية } \\
\hline$\varepsilon$ & 7 & عدم تجريف الأرض أو البناء عليها \\
\hline$r \cdot, r$ & $\varepsilon$ & إستخدام مخلفات المحاصيل كاسمدة عضوية \\
\hline 11 & YI & زر اعة محاصيل مجهدة بالتبادل مع محاصيل مفيدة للتربة كالبقوليات \\
\hline$\Lambda, \varepsilon$ & iv & عدم الاستخدام المفرط للمبيدات \\
\hline 07 & 11. & لا تعرف كيفية صيانة مورد الارض \\
\hline \multicolumn{3}{|c|}{ المعرفة بالحقائق المتعلقة بمورد مياه الرى } \\
\hline r & $\circ$ & نقص مياه الرى من المنبع الرئيسى \\
\hline r) & $\S$ & الإهدار فى مياه الرى ناتج عن اتباع طرق الرى التقليديه \\
\hline ro & 71 & لا يوجد وعى عند الأفر اد بأهية المياه وتقنين إستهلاكها \\
\hline ir & $r \varepsilon$ & تلوث مياه التز ع بفو ارغ المبيدات \\
\hline rq & 07 & لا تعرف الأسباب المؤدية لتلوث و إستنز اف مياه الرى \\
\hline \multicolumn{3}{|c|}{ كيفية صيانة مورد مياه الرى } \\
\hline$\circ$ & 1. & زر اعة محاصيل إحتياجتها المائية منخفضة \\
\hline 19,0 & rᄉ & إتباع الرى بالرش أو التتقبط \\
\hline$r$. & ov & تسوية الأرض بالليزر يقلل من الإحتياجات المائية \\
\hline 1. & r. & عدم القاء الفوارغ الخاصة بالمبيدات فى الترع \\
\hline ro,o & 79 & لا تعرف كيفية صيانة مورد مياه الرى \\
\hline \multicolumn{3}{|c|}{ المعرفة بالحقائق المتعلقة بمورد الهواء } \\
\hline 11 & Y) & الإستخدام المفرط للمبيدات وتطايرها مع الرياح \\
\hline 10 & 177 & حرق مخلفات المحاصيل تلوث الهو اء \\
\hline$\varepsilon$ & $\mathrm{V}$ & قطع الأشجار و النخيل بضر بالهو اء \\
\hline \multicolumn{3}{|c|}{ كيفية صيانة مورد الهواء } \\
\hline 11 & ro & عدم رش المبيدات فى وجود رياح \\
\hline$\vee \neg, \varepsilon$ & $1 \leq \wedge$ & عدم حرق مخلفات المحاصيل \\
\hline 0,7 & 11 & زر اعة الأشجار الخضر اءعلى رأس الحقول \\
\hline \multicolumn{3}{|r|}{ مستويات الوعى البيئى } \\
\hline$\%$ & عدد ع & الفئات \\
\hline ro & $\uparrow \Lambda$ & منخفض( ا - 1 درجة) \\
\hline$\varepsilon$ & $\vee \wedge$ & متوسط (9- 0 ادرجة) \\
\hline To & $\sum \wedge$ & مرتفع (T ا درجة فأكثر) \\
\hline $1 \cdots$ & $19 \leq$ & 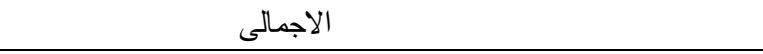 \\
\hline
\end{tabular}

المصدر : جمعت وحسبت من إستمار ات الاسنتيان

ثانياً :مستوى معرفة المرأة الريفية بحفظ الموارد الوراثية النباتية

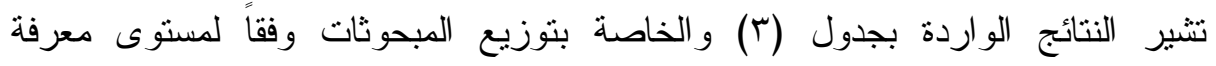

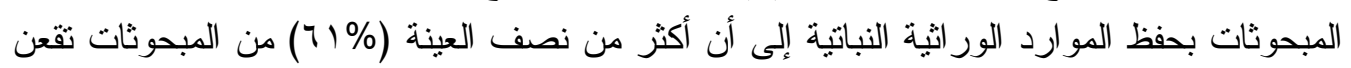


فى فئة المستوى المتوسط من المعرفة بحفظ الموارد الوراثية النباتية، وسوف يتم تفسير تلك النتيجة

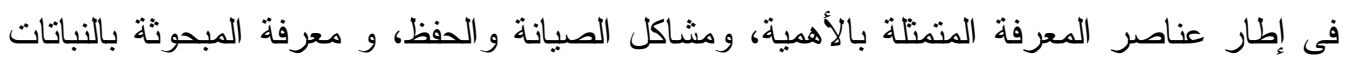
المهددة بالانقر اض، و طرق حماية المو ارد الور اثية النباتية.

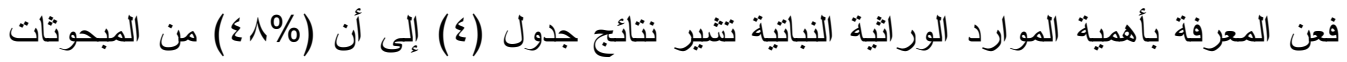

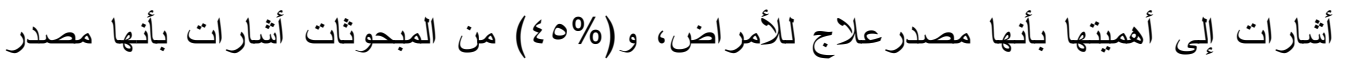

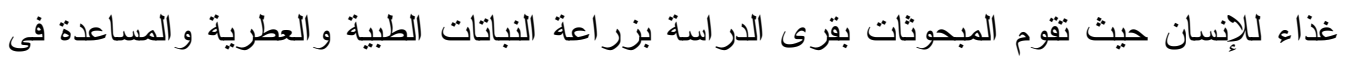

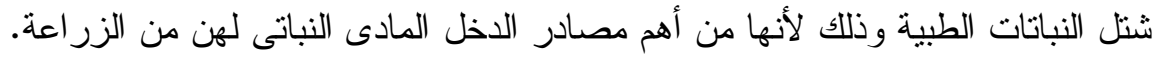

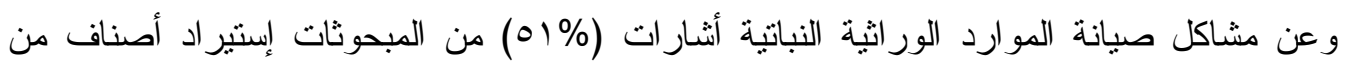

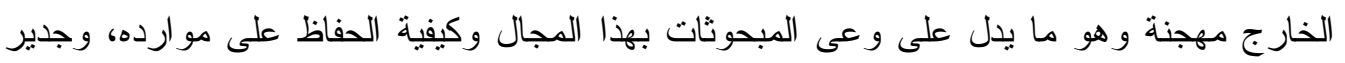
بالذكر أن هذا الوعى ناتج عن الإحتياج المادى لهن ومن من ثم محاولة معرفة كافة الأمور عن مصدر الدخل المتمنل بزر اعة المحصول وحفظه.

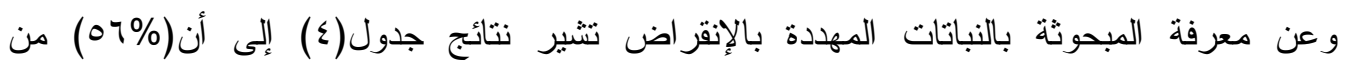

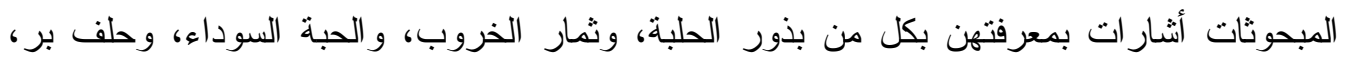

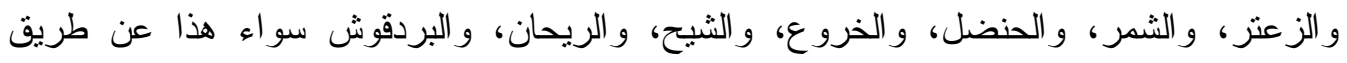

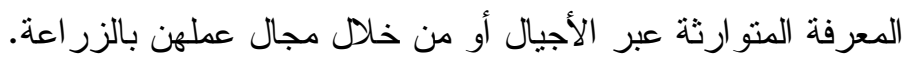

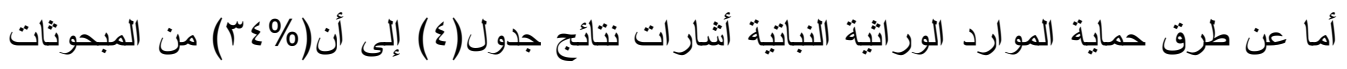

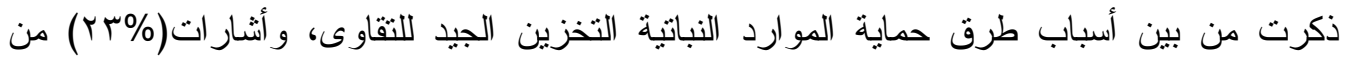

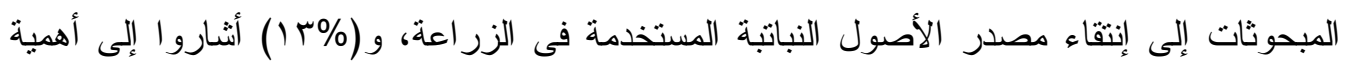
التوارث المعرفى بين الأجيال فيما يتعلق بالموارد الور الثئة النباءتية.

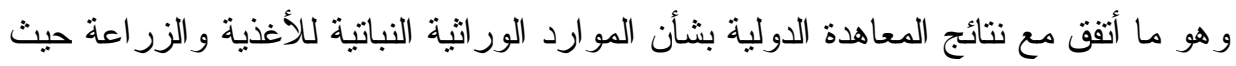

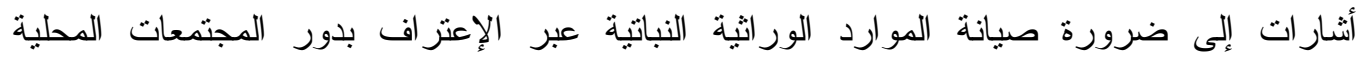

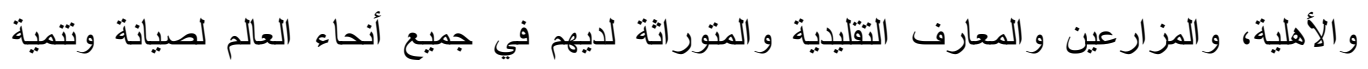

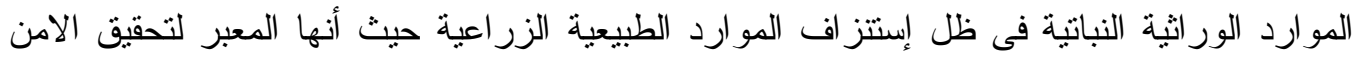

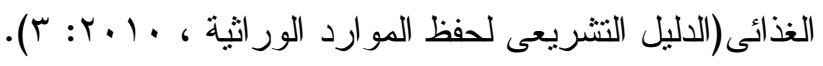
جدول ( r ) توزيع المبحوثات وفقاً لمستوى المعرفة بحفظ الموارد الوراثية النباتية

\begin{tabular}{|c|c|c|}
\hline \multicolumn{3}{|c|}{ بقرى الاراسة } \\
\hline$\%$ & تكرار & مستويات المعرفة \\
\hline 11 & To & منخفض (VIV-זدرجة) \\
\hline 71 & 111 & متوسط (1) - . · درجة) \\
\hline r) & «1 & مرتفع ( آفأكثر) \\
\hline $1 \ldots$ & $19 \varepsilon$ & المجموع \\
\hline
\end{tabular}

المصدر : جمعت وحسبت من إستمار ات الاستبيان

جدول (؛) توزيع المبحوثات وفقا لعناصر المعرفة بحفظ وصيانة الموارد الوراثية النباتية $\%$ عدد عناصر المعرفة - م 


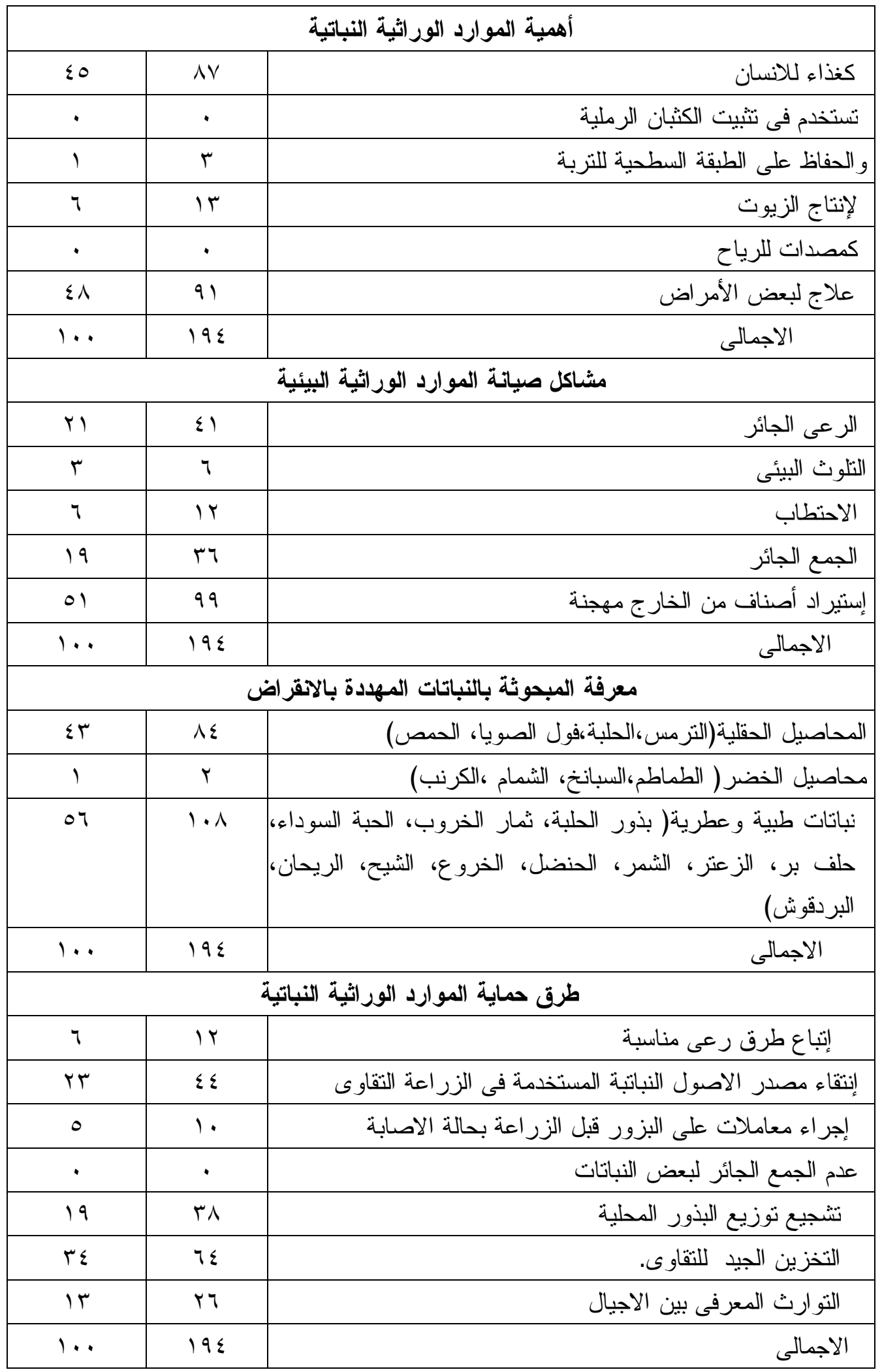

ثالثاً : طبيعة العلاقة بين المتغيرات المستقلة المدروسة ودرجة الوعى البيئى للريفيات بصيانة بعض الموارد الطبيعية الزراعية بقرى الاراسة: 
أ. طبيعة العلاقة بين المتغيرات المستقلة المدروسة ودرجة الوعى البيئى بصياتة التربة الزراعية بقرى الار اسة. ينص الفرض الإحصائي على "علم وجود علاقة معنوية بين المتغير ات المستقلة التالية(عمر

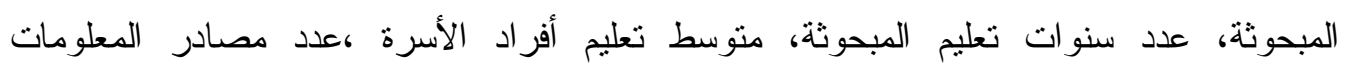

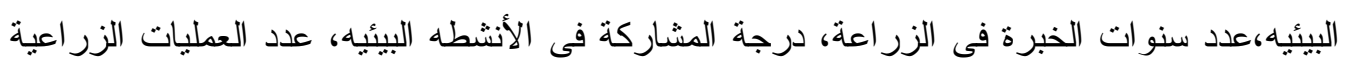

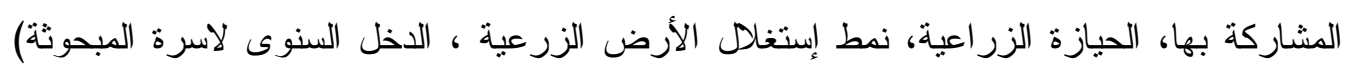

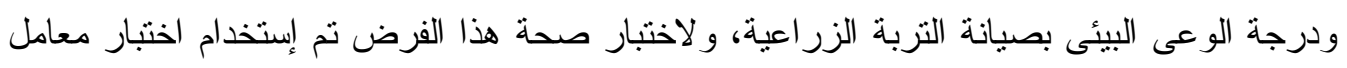
الارتباط البسيط لبيرسون.

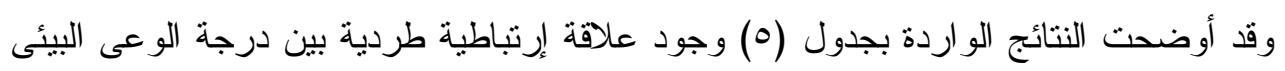

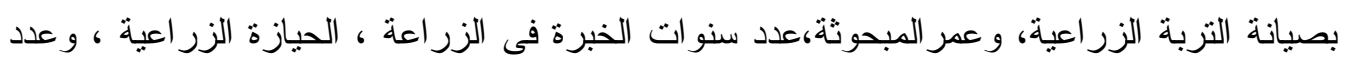

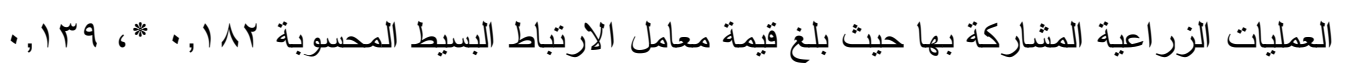

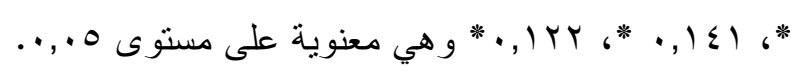

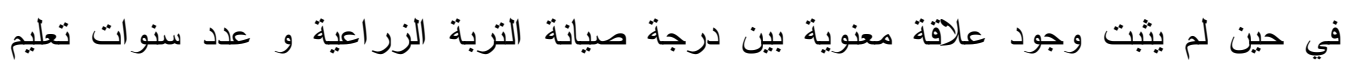
المبحوثة، عدد مصادر المعلومات البيئيه، درجة المشاركة فى الأنشطه البيئه كدرجة نمط إستغلال

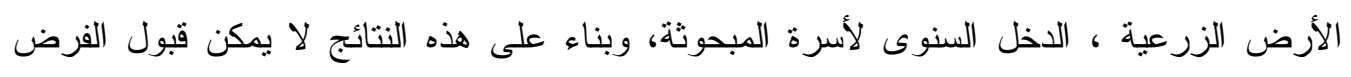

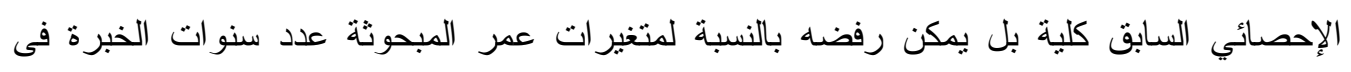

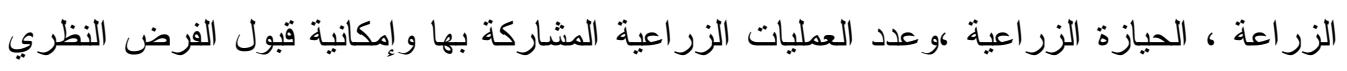

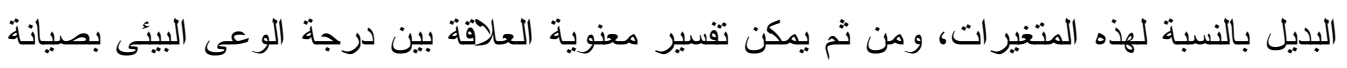

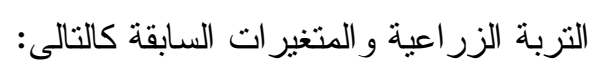
عمر المبحوثة : بزيادة عدد سنوات عمر المبحوثة تزداد خبر اتها فى شئون الزر اعة وبالتالى تحاول

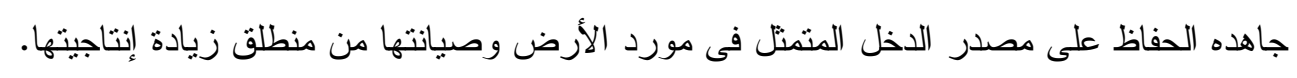

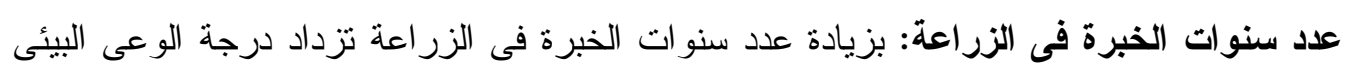

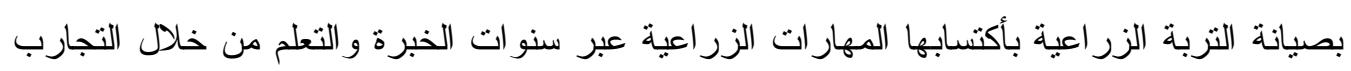
المتعددة لها بالزر اعة. الحيازة الزراعية : بزيادة الحيازة الزراعية تزداد درجة الوعى البيئى بصيانة التربة من خلال

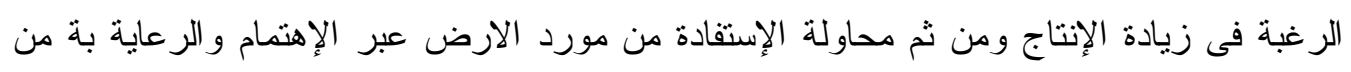
خلا التسميد وزيادة الخصوبة. عدد العمليات الزراعية المشاركة بها: بزيادة عدد العمليات الزر اعية التى نتسارك بها المر أة الريفية

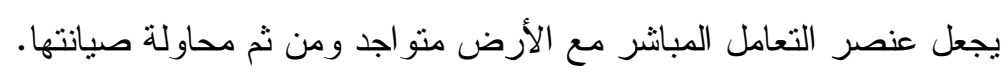
ب. طبيعة العلاقة بين المتغيرات المستقلة المدروسة ودرجة الوعى البيئى بصياتة مياه الرى بقرى الار (سة.

ينص الفرض الإحصائي على "علم وجود علاقة معنوية بين المتغير ات المستقلة التالية(عمر

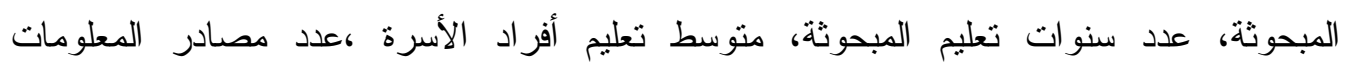


البيئيه،عدد سنوات الخبرة فى الزر اعة، درجة المشاركة فى الأنشطه البيئيه، عدد العمليات الزر اعية

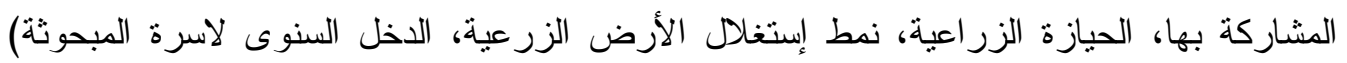
ودرجة الوعى البيئى بصيانة مياه الرى، ولاختبار صحة هذا الفرض تم إستخدام إختبار معامل

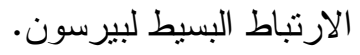

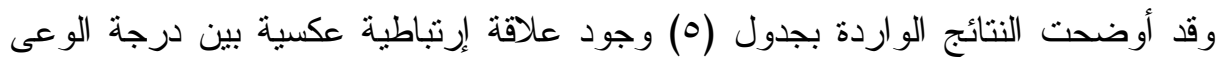

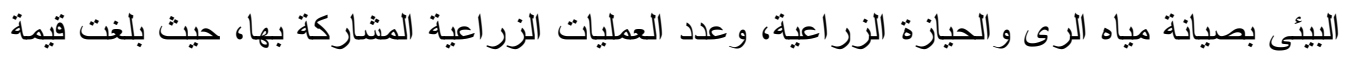

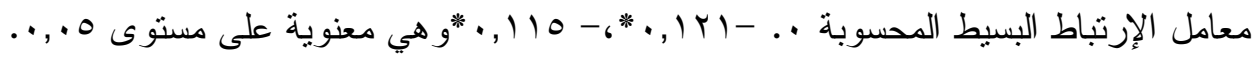

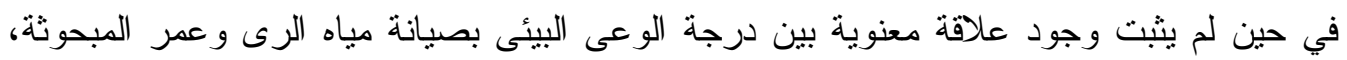
عدد سنوات تعليم المبحوثة، عدد مصادر المعلومات البيئيه، درجة المشاركة فى الأنشطه البيئه ، درجة نمط إستغلال الأرض الزرعية، الدخل السنوى لاسرة المبحوثة) وبناء على هذه النتائج لا يمكن

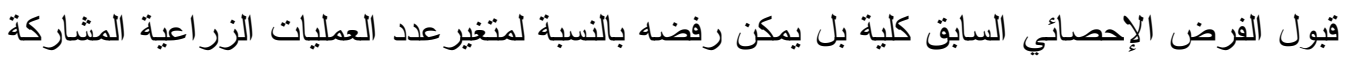

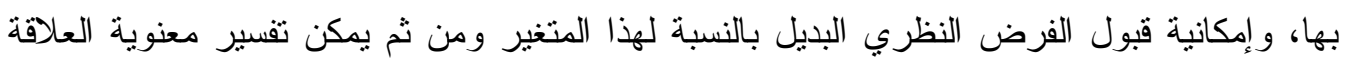

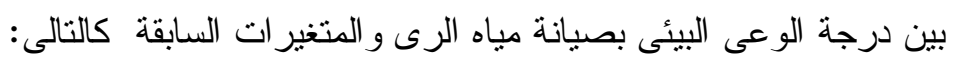

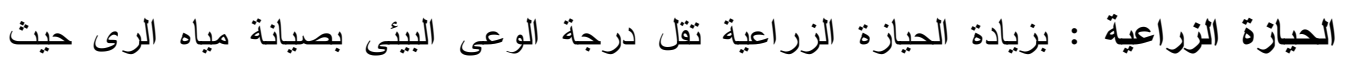

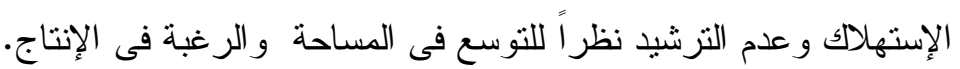

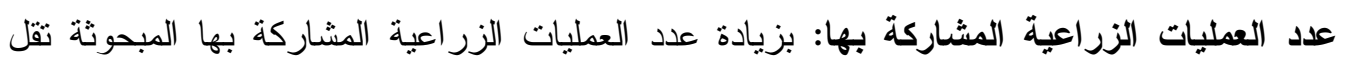

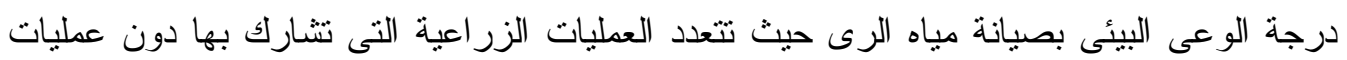

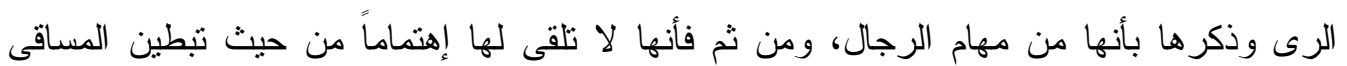
و التطهير ،وعدم الإهنمام بعناصر الحماية و الصون لمياه الرى بهن.

ت. طبيعة العلاقة بين المتغيرات المستقلة المدروسة ودرجة الوعى البيئى بصياتة الهواء بقرى

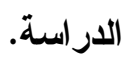

ينص الفرض الإحصائي على "عدم وجود علاقة معنوية بين المتغيرات المستقلة التالية(عمر

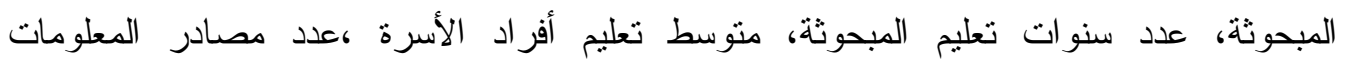

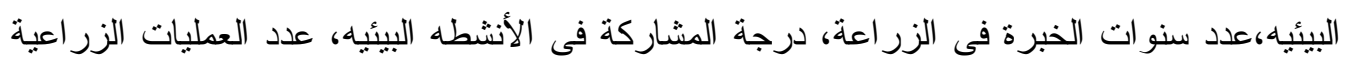

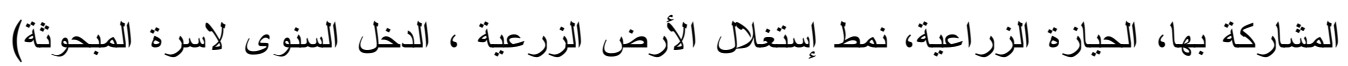

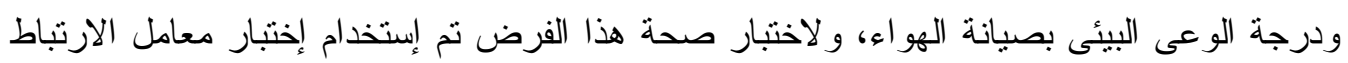
البسيط لبيرسون.

وقد أوضحت النتائج الواردة بجدول (0) وجود علاقة إرتباطية طردية بين درجة الوعى البيئى

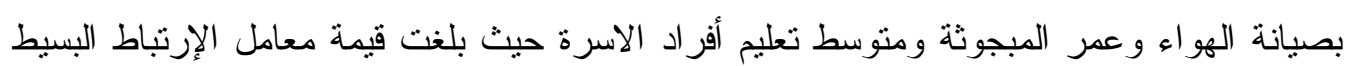

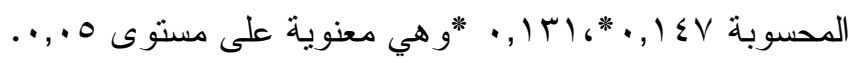
في حين لم يثبت وجود علاقة معنوية بين درجة الوعى البيئى بصيانة مياه الرى و عدد مدئه مصادر

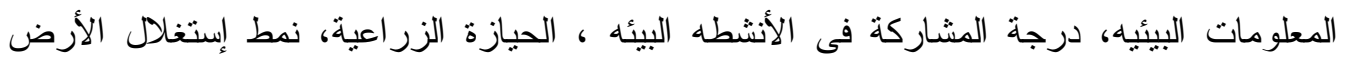

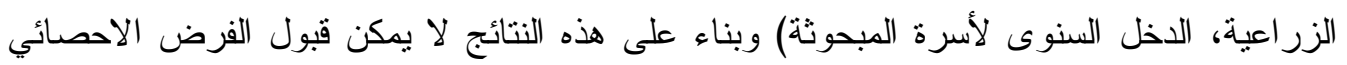


السابق كلية بل يمكن رفضه بالنسبة لمتغيرى عمر المبحوثة ومنوسط تعليم أفراد الاسرة وإمكانية قبول الفرض النظري البديل بالنسبة لهذه المتغيرات. ومن ثم بمكن تفسير معنوية العلاقة بين درجة الوعى البيئى بصيانة الهواء و المتغيرات السابقة

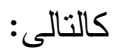
عمر المبحوثة: بزيادة عدد سنوات عمر المبحوثة يزداد درجة الوعى بصيانة الهو اعحيث يتكون

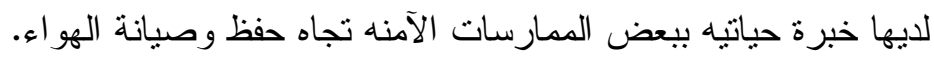

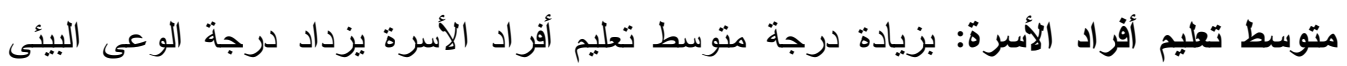

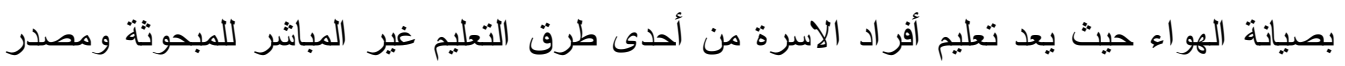
لل المعلومات. جدول(0) قيم معاملات الارتباط البسيط بين المتغيرات المستقلة ودرجة الوعى البيئى بصيانة

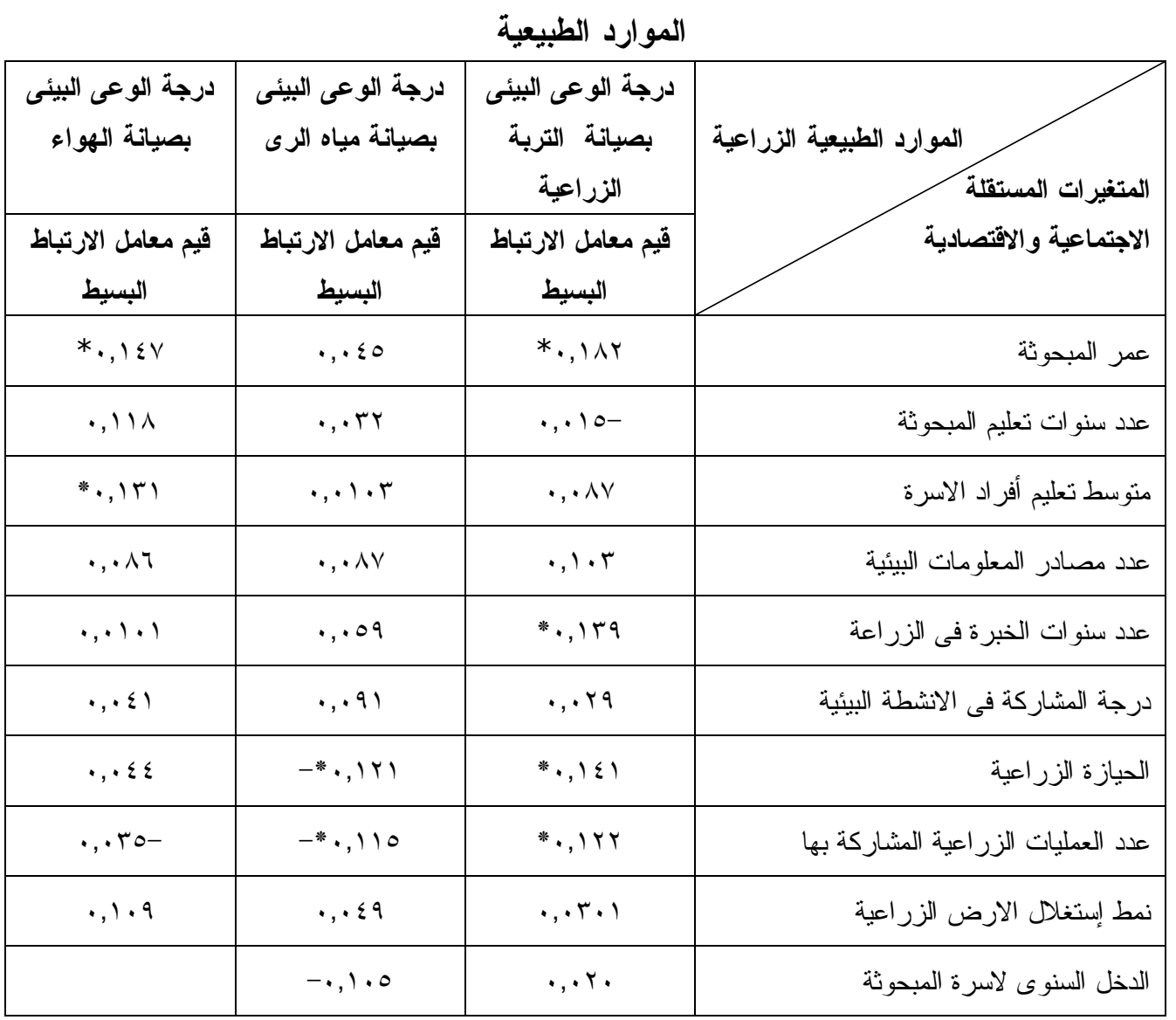

المصدر : جمعت وحسبت من إستمار ات الاستبيان

رابعاً: التعرف على المشكلات الإجتماعية والإقتصادية الناتجة عن إستنزاف الموارد الطبيعية

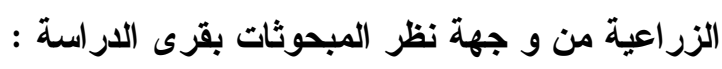

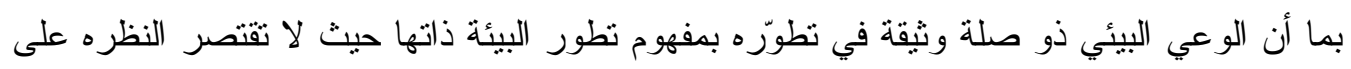

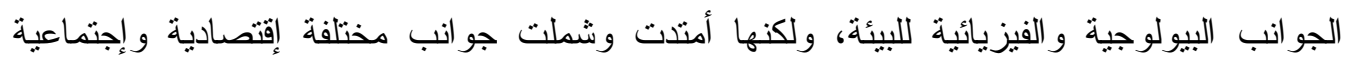


للبيئة، وهو ما ينم أستخلاصة من سرد تلاك المشكلات أن النساء الريفيات يوجد لايهن إحساس وشعورقوى بالمردود الإجتماعى والإقتصادى لإستنز اف الموارد الطبيعية الزراعية حيث نتحمل

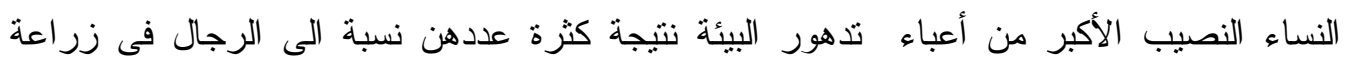
الكفاف و الإعتماد على المو ارد الطبيعية فى ظل نظم ايكولوجية سريعة الناثر بتغير المناخ. وتتثير نتائج جدول(؟) و الخاصة بتوزيع المبحوثات وفقاً للمشكلات الإجتماعية و الإقتصادية الناتجة عن إستتز اف الموارد الطبيعية الزراعبة إلى تعرض المبحوثات إلى عدد من المشكلات

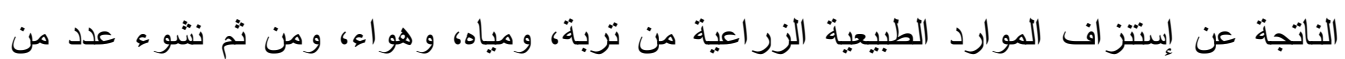
المشكلات سوف يتم التعرض إليها كالتالى:

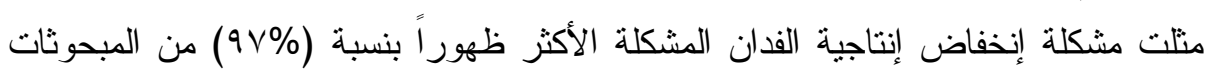

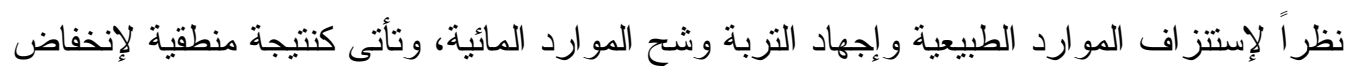

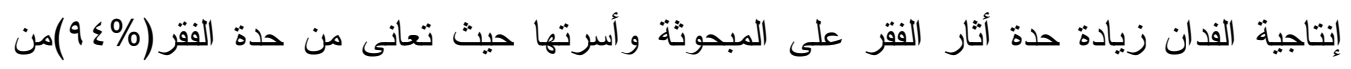

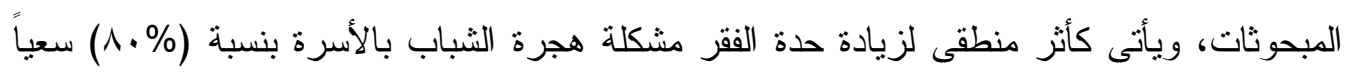

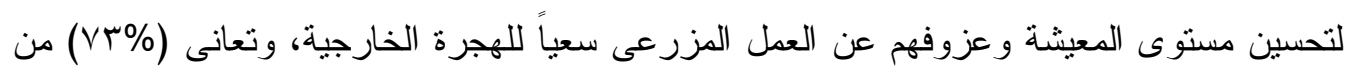

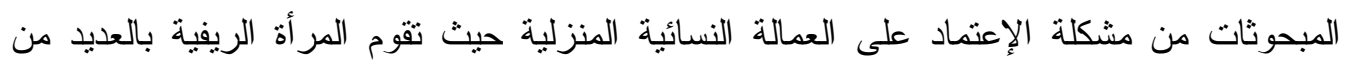

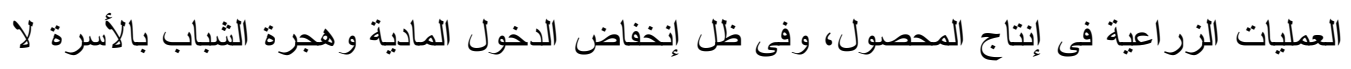
يتم اللجوء إلى إستخدام عمالة زر اعية أخرى للمساعدة ويتم الإعتماد الكلى على العمالة النسائية المنزلية بالأعمال المزرعية.

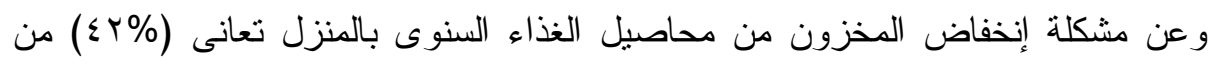

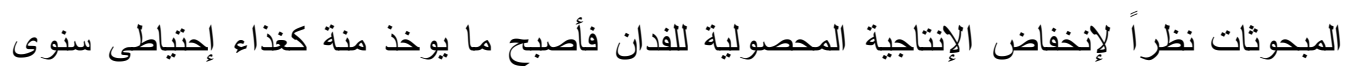

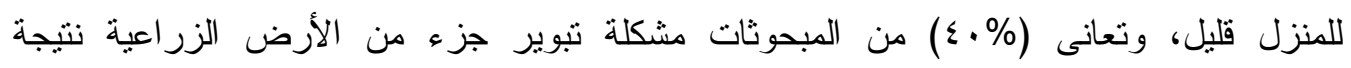

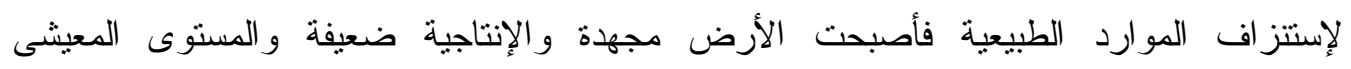

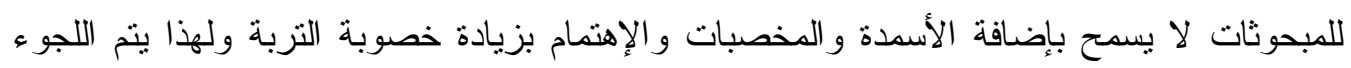
إلى تبوير جزء من الأرض الزر اعبة لتقليل النفقات المادية.

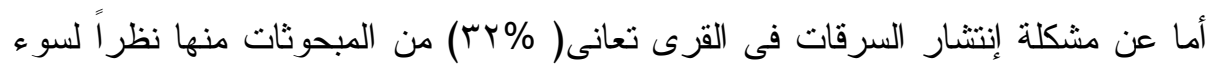
سلوك بعض الأفراد ومن ثم اللجوء إلى السرقة، وقد ذكرت المبحوثات بأنهن تعرضن لسرقة ماكينات الرى و المو اثىى وحتى المحاصيل الزر اعية بعد جمعها وتركها بالحقل وتجهيز ها للنقل.

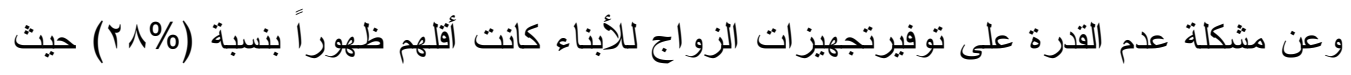
نقص العائد المادى من بيع المحصول مصدر الدخل الاساسى للمز ارعين.

جدول (؟) توزيع المبحوثات وفقا لتكر ار ات المشكلات الإجتماعية و الإقتصادية الناتجة عن إسنتز اف الموارد الطبيعية الزراعية

\begin{tabular}{|c|c|c|c|}
\hline الترتيب & $\%$ & N= التكر ار ـ 9 ا & المشكلة \\
\hline 1 & १४ & 19. & إنخفاض إنتاجية الفدان \\
\hline
\end{tabular}




\begin{tabular}{|c|c|c|c|}
\hline r & $9 \leq$ & $1 \wedge \varepsilon$ & المعاناة من زيادة حدة الفقر \\
\hline r & $\wedge \cdot$ & 107 & هجرة الثباب بالأسرة وعزوفهن عن العمل الزر اعى \\
\hline$\varepsilon$ & $\mathrm{Vr}$ & $1 \leq r$ & زيادة الإعتماد على العمالة النسائية المنزلية \\
\hline 0 & $\varepsilon r$ & Ar & انخفاض المخزون من محاصيل الغذاء السنوى للمنزل \\
\hline 7 & $\varepsilon$ & $\vee \wedge$ & تبوير جزء من الأرض \\
\hline v & rt & Tr & إنتشار السرقة فى القرى \\
\hline$\wedge$ & r^ & $0 \leqslant$ & عدم القدرة على توفيرتجهيز ات الزو اج للأبناء \\
\hline
\end{tabular}

المصدر : جمعت وحسبت من إستمار ات الاستبيان

خامساً: التعرف على أوجة الضعف والقوة والفرص والتحديات لصيانة الموارد الطبيعية الزراعية من وجهة نظر المبحوثات بقرى الدراسة:

تشير نتائج جدول (V) إلى كيفية صيانة الموارد الطبيعية الزر اعية عبر التعرف على أوجة

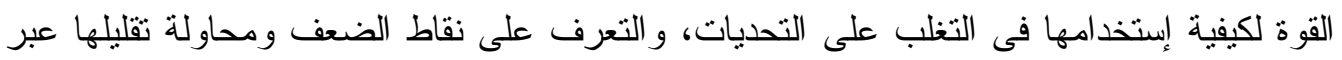
استخدام أوجة الفرص المتاحة وهو ما سوف ينت عرضة كالتالى.

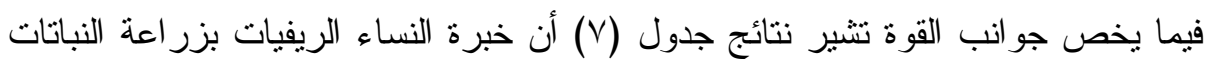

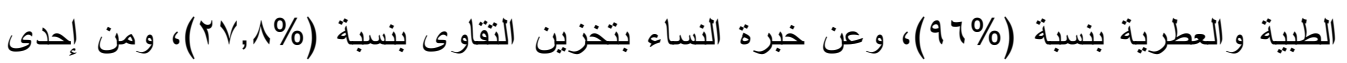

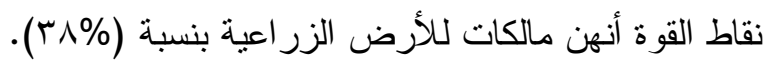

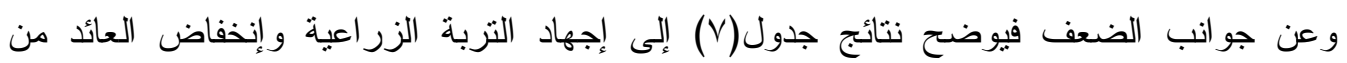

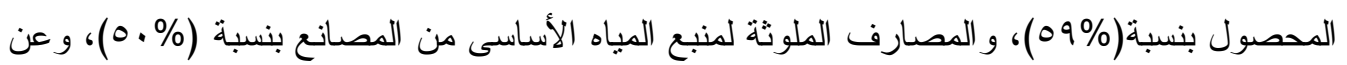

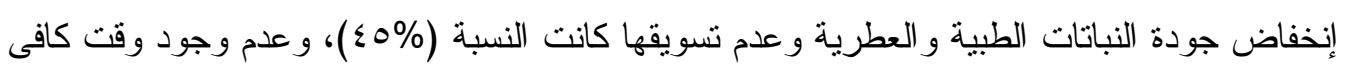

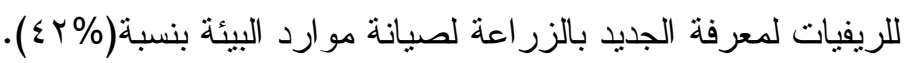

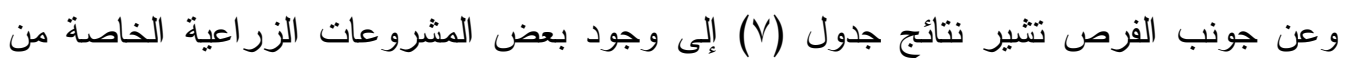

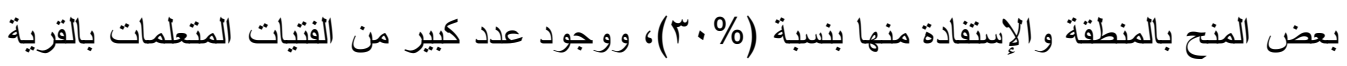

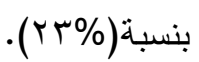
وعن جوانب التحديات التى تتكل عقبة أمام عمل المبحوثات حيث الرغبة فى تحقيق إنتاجية عالية

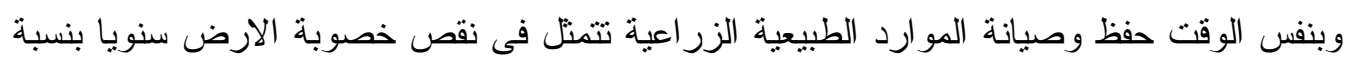

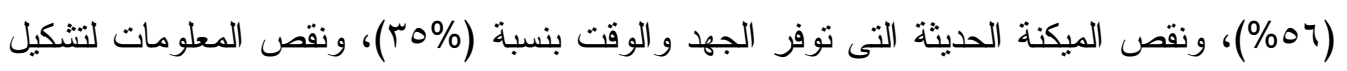

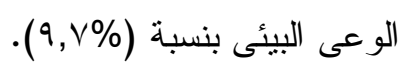

وقد تم التوصل إلى نموذج (r) حيث إستخدام نقاط القوة للتخلب على التحديات كمحاولة إستخدام

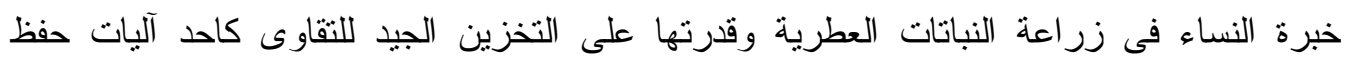
الموارد الور اثية النباتية النى نساعد على حفظ خصوبة الأرض وعدم الهدر المائى عبر دعمهن بالمعلومات التى تشكل الوعى البيئى من خلال الزيار ات الميداعية النية.

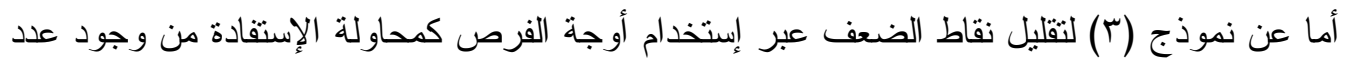
من الفتيات المتعلمات بالقرية كقاعدة للقيادات النسائية المتعلمة التى تقوم بدورها بنقل المعرفة 
و الجديد الى الريفيات العاملات بالزر اعة التى تتعدد أداو ارهن و لا يوجد لديهن الوقت الكافى للذهاب

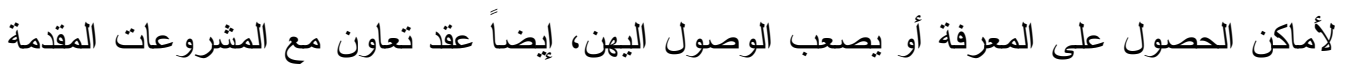

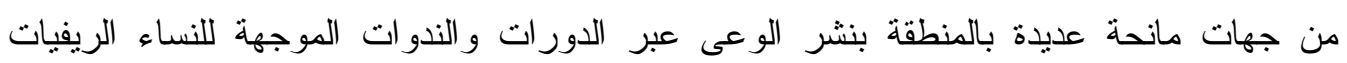

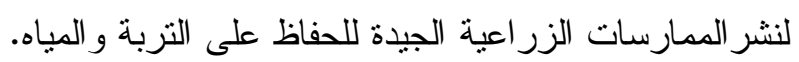

جدول (V) جو انب القوة و الضعف و الفرص و التحديات لصيانة بعض الموارد الطبيعية الزر اعية

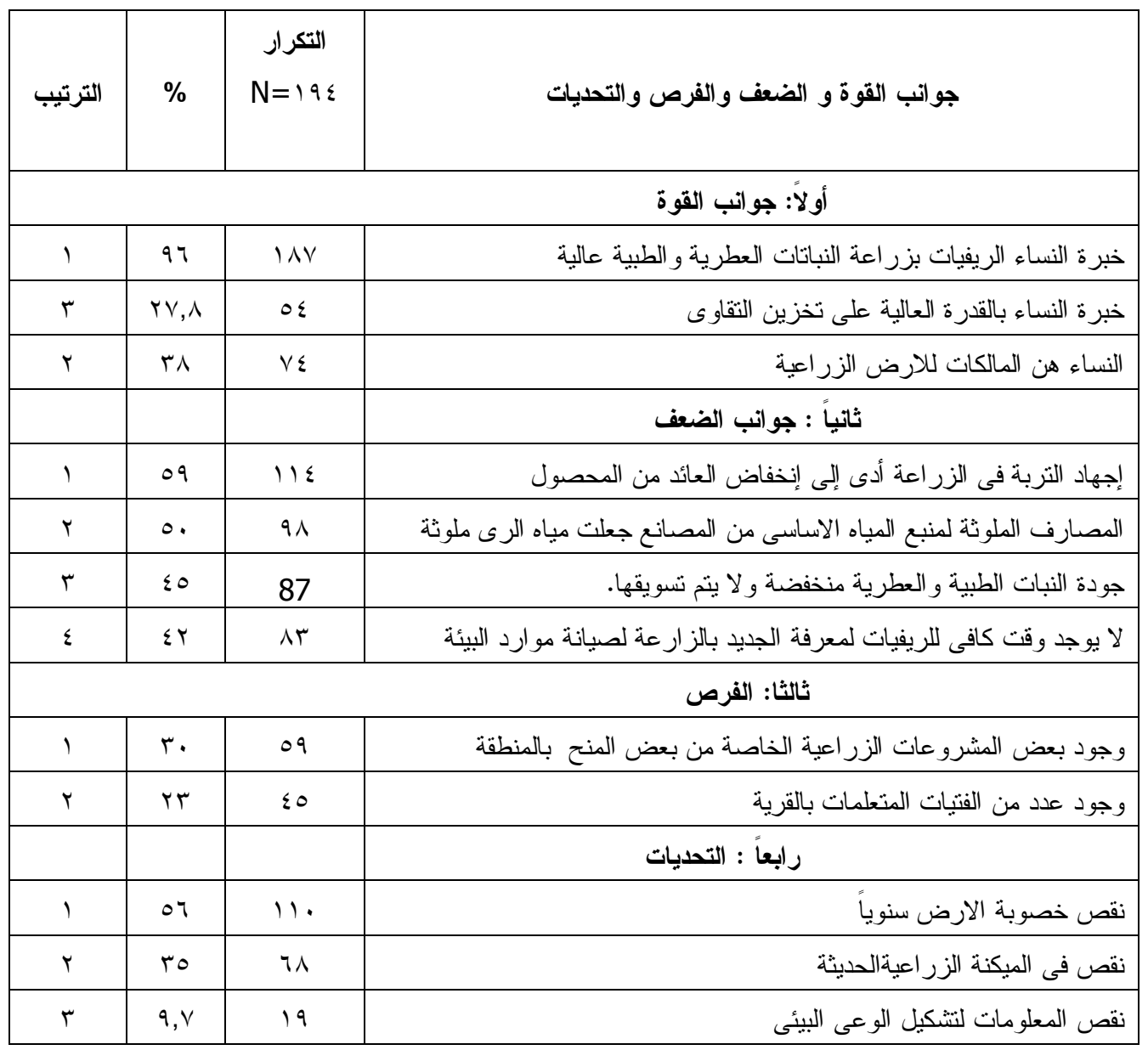

المصدر : جمعت وحسبت من إستمار ات الاستبيان المعئ

نموذج (r) إستخدام نقاط القوة للتغلب على التحديات

\begin{tabular}{|l|l|l|}
\hline نقاط القوة & Strengths \\
\hline
\end{tabular}




\begin{tabular}{|c|c|}
\hline ST( Stratige ) & حبث النخزين النساء الريفيات بزراعة النباتات العطرية وقدرتهن \\
\hline نقاط التحديات (Threats) & ST ( stratige): \\
\hline 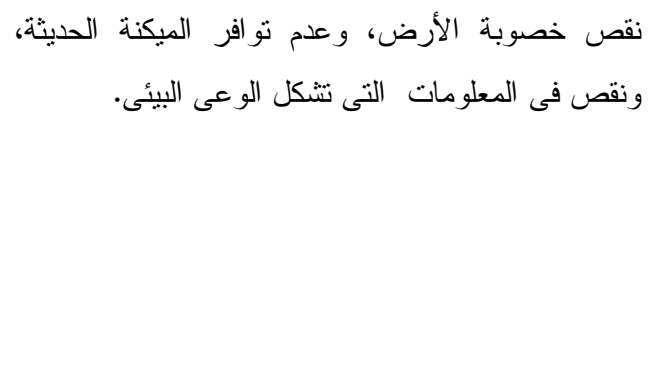 & 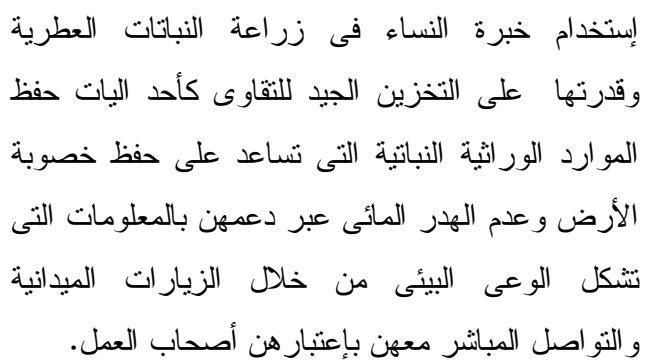 \\
\hline
\end{tabular}

نموذج (ץ) نموذج تقليل نقاط الضعف عبر إستخدام أوجة الفرص

\begin{tabular}{|c|c|}
\hline \multirow{2}{*}{$\begin{array}{l}\text { الفرص يف بكن نقليل نقاط الضعف عبر إستخدام أوجة } \\
\text { WO( Stratige ) }\end{array}$} & (weaknesses) \\
\hline & 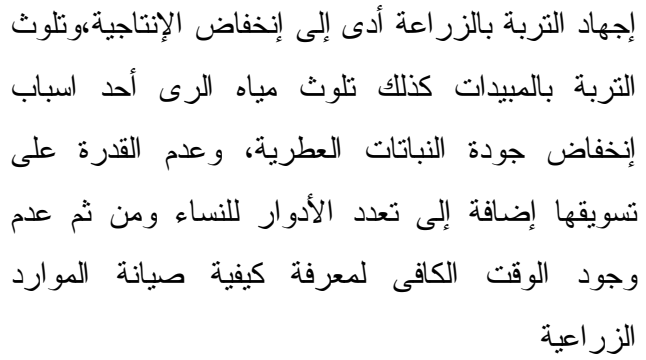 \\
\hline نقاط الفرص (Opportunities) & WO ( stratige): \\
\hline 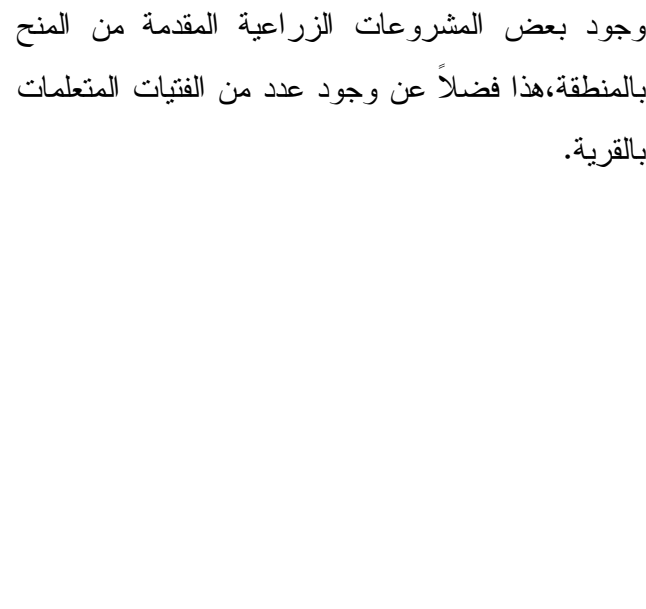 & 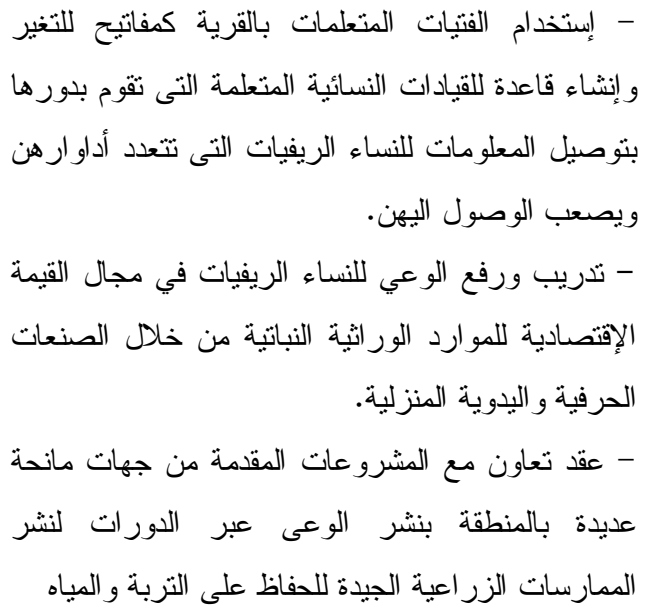 \\
\hline
\end{tabular}

المصدر : تم انثاء هذ النموذج بالإعتماد على نتائج إستمار ات الإستبيان بالبحث.

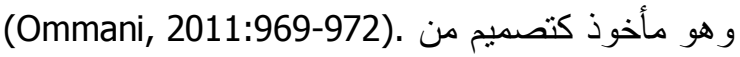


ا. فى ضوء ما أظهرته النتائج أن (\% •ـ؛) من المبحوثات تقع فى المستوى المتوسط من

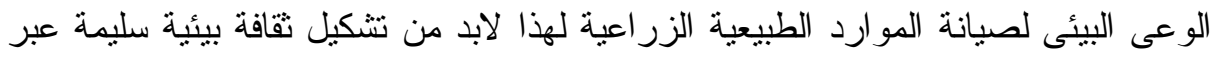

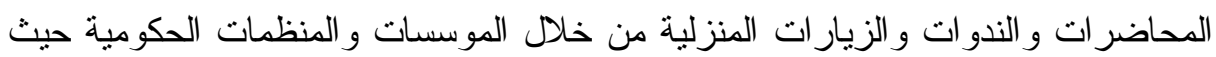
أن المرأة الريفية سوف تعد ناقل للثقافة البيئة الصحيحة عبر الاجيال، بالاضافة الى التدخل

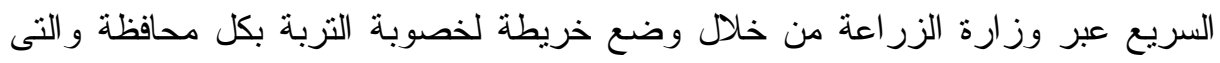
تحدد نوعية الأرض ونوع المحصول المناسب وكمية الاسمدة وماهى آليات صيانة وحفظ لرّل

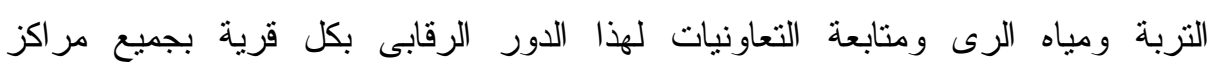
المحافظات.

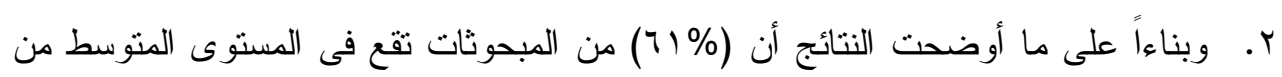

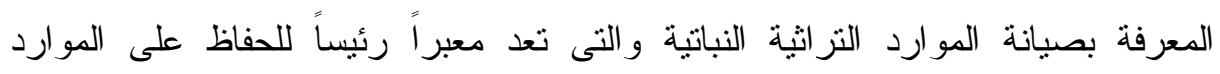

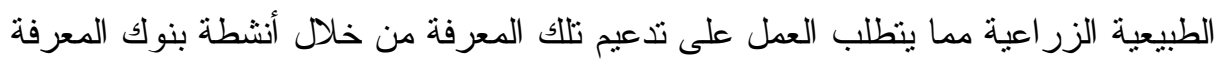

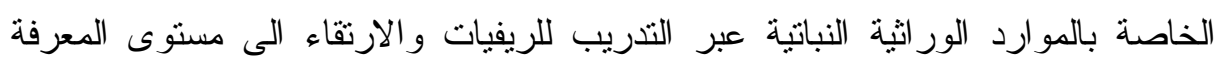
المرتفع.

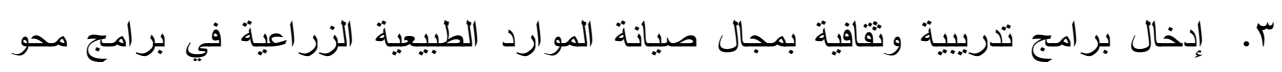

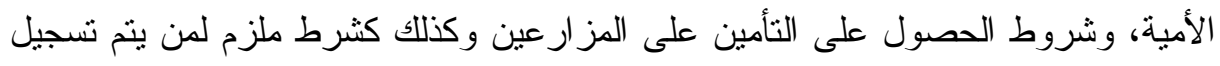
المهنة "مزارعه" أو "فلاحه" في بطاقة الرقم القومي فكما يتم المطالبه بحقوق تمكين الريفيات يجب إيضا المطالبة بو اجباتها نحو صيانة البيئة.

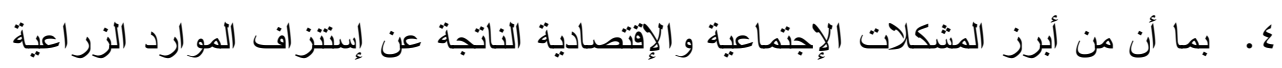

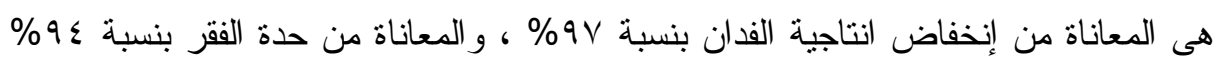

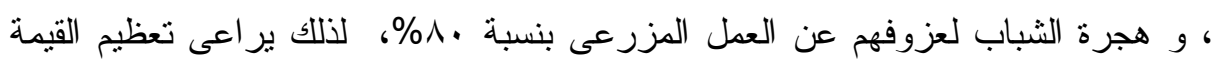

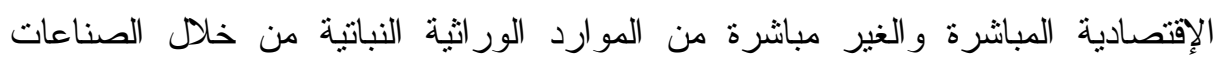

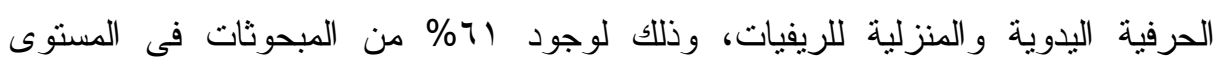
المعرفى المتوسط بحفظ الموارد الور اثية النباتية.

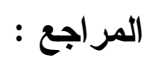

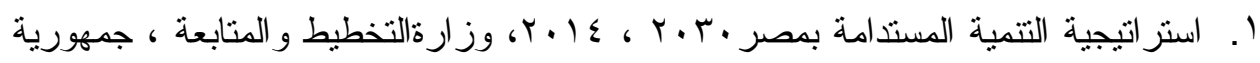
مصر العربية.

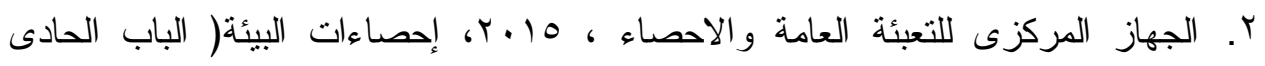
و العشرون)، الكتاب الاحصائى السنوى ، جمهورية مصر العربية.

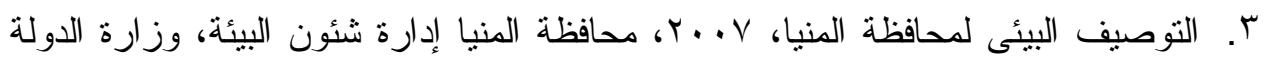

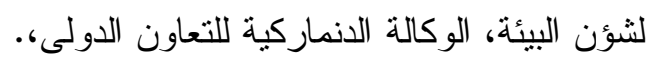

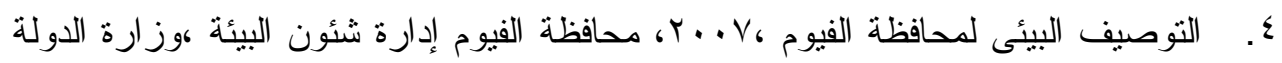

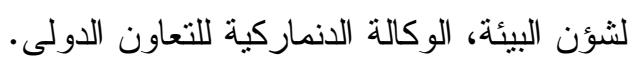


○. سليم ، أمينة محمد، 10 ـ r، علاقة بعض المتغيرات الاجتماعية والثقافية لأفراد الاسرة

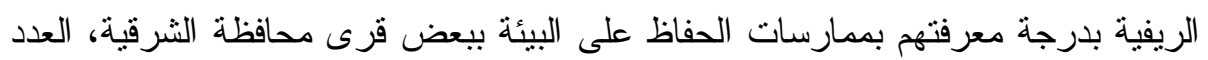

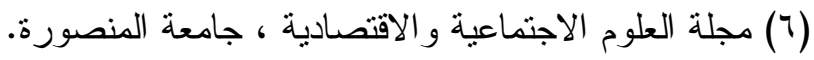

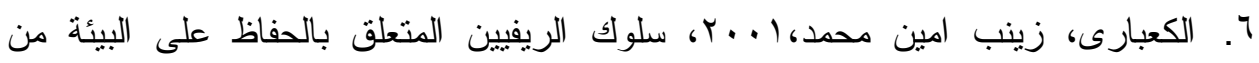
منظور النوع الإجتماعى بقرينين بمحافظتى القليوبية وبنى سويف ، رسالة دكتور اة ، كلية الئل زر اعة ، جامعة القاهرة .

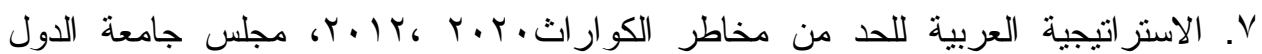

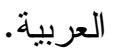
^. الأبعاد الانسانية لإدارة الموارد الطبيعية، 7 أب، مقالة منشورة، منظمة الاغذية و الزر اعة

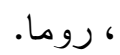

9. بركات ، محمد محمود ، . .. . ب، الإحصاء الإجتماعى وطرق القياس، جامعة عين شمس.

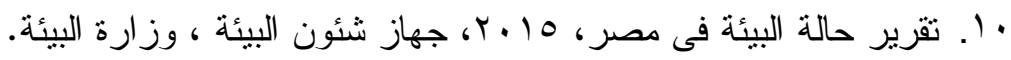

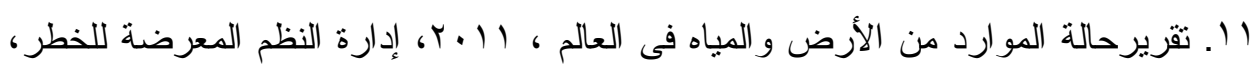

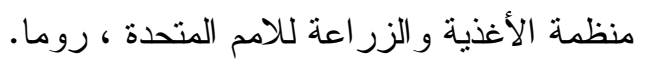

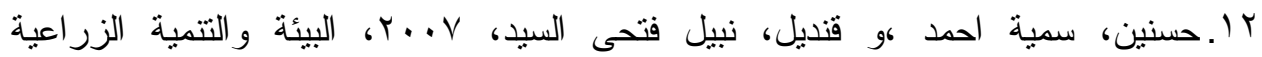

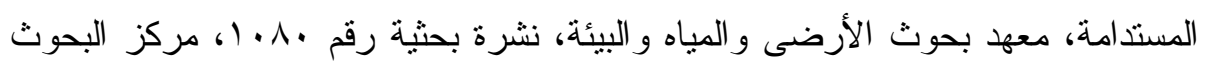

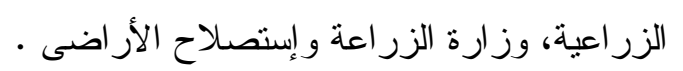

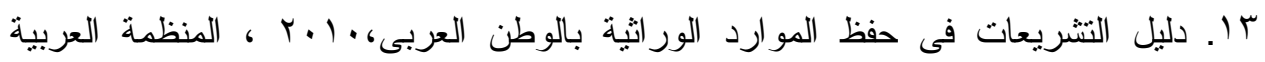
للتنمية الزر اعبة ، جامعة الدول العربية

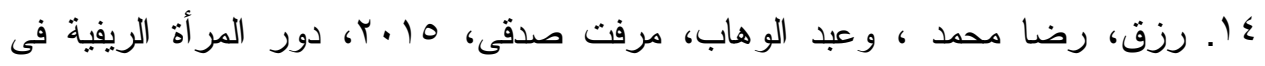

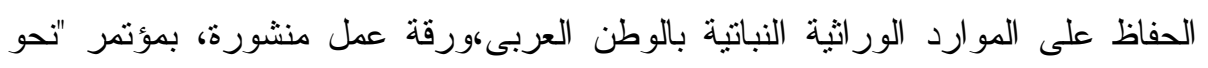

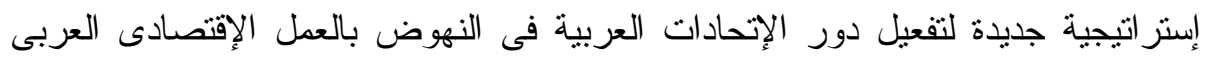

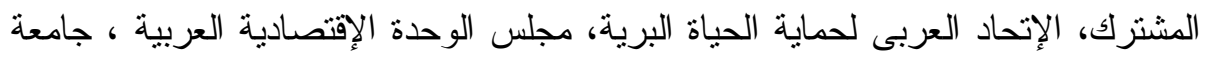

$$
\text { الدول العربية. }
$$

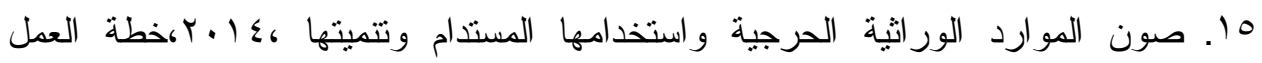

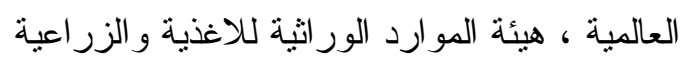

17

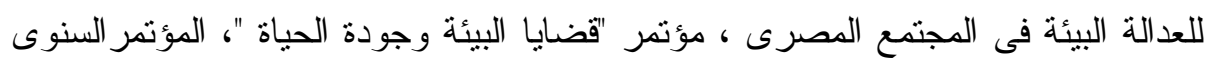
السادس عشر ، المركز القومى للبحوث الاجتماعية و الجنائية.

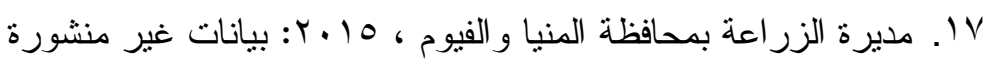

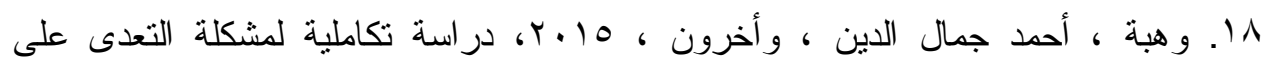

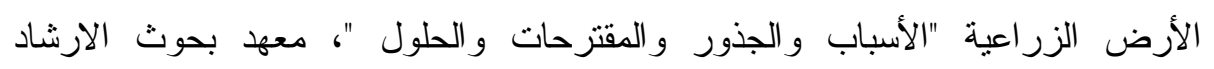
الزراعى و التتمية الريفية ، مركز البحوث الزراعية الاعبة ، وزارة الزراعة والعة واستصلاح 
526 ENVIRONMENTAL AWARENESS LEVEL OF RURAL WOMEN TO MAINTENANCE SOME AGRICULTURAL NATURAL RESOURCES IN MINYA AND FAYOUM GOVERNORATES

19. World Bank (2005), A Water Sector Assessment Report on the Countries of the Cooperation Council of the Arab States of the Gulf.

20. John Ruane \& Andrea Sonnino (2006), The role of biotechnology in exploring and protecting agricultural genetic resources, FAO, ROME.

20. Anja Kollmuss \&Julian Agyeman (2002), Mind the Gap: Why do people actenvironmentally and what are the barriers to proenvironmental behavior, Environmental Education Research Routledge.

21. Ommani, Ahmad reza (2011), Strategies of Rural Development in Shoushtar Township of Iran (Applying SWOT method)، pp: 969-972 .7(1), Journal of American Science.

22. www.fao.org/gender/gender-home visited at 8;pm 11/8/2016 